\title{
The in vitro antiplasmodial and antiproliferative activity of new ferrocene- based $\alpha$-aminocresols targeting hemozoin inhibition and DNA interaction
}

\author{
Mziyanda Mbaba, ${ }^{[a]}$ Laura M.K. Dingle, ${ }^{[b, c]}$ Tarryn Swart, ${ }^{[b, d]}$ Devon Cash, ${ }^{[b, c]}$ Dustin \\ Laming, ${ }^{[b, d]}$ Jo-Anne de la Mare, ${ }^{[b, c, d]}$ Dale Taylor, ${ }^{[e]}$ Heinrich C. Hoppe,${ }^{[b, d]}$ Christophe \\ Biot, ${ }^{[\mathrm{ff}]}$ Adrienne L. Edkins, ${ }^{[\mathrm{b}, \mathrm{c}, \mathrm{d}]}$ Setshaba D. Khanye ${ }^{*[\mathrm{a}, \mathrm{d}, \mathrm{g}]}$
}

[a] Faculty of Science, Department of Chemistry, Rhodes University, Grahamstown, 6140, South Africa

[b] Faculty of Science, Department of Biochemistry and Microbiology, Rhodes University, Grahamstown, 6140, South Africa

[c] Biomedical Biotechnology Research Unit, Rhodes University, Grahamstown, 6140, South Africa

[d] Centre for Chemico- and Biomedicinal Research, Rhodes University, Grahamstown, 6140, South Africa

[e] Faculty of Medicine, Division of Clinical Pharmacology, University of Cape Town,

Observatory, Cape Town 7925, South Africa

[f] Univ. Lille, CNRS, UMR 8576 - UGSF - Unité de Glycobiologie Structurale et Fonctionnelle, F-59000 Lille, France

[g] Faculty of Pharmacy, Division of Pharmaceutical Chemistry, Rhodes University, Grahamstown, 6140, South Africa

Corresponding authors

Tel: +27 46603 8397; Fax: +27 466037506

E-mail addresses: s.khanye@ru.ac.za (S.D. Khanye), christophe.biot@univ-lille.fr (C. Biot) 


\begin{abstract}
Conjugation of organometallic complexes to known bioactive organic frameworks is a proven strategy revered for devising new drug molecules with novel modes of action. Herein, we present the in vitro antimalarial and antiproliferative investigation of ferrocenyl $\alpha$-aminocresol conjugates assembled by amalgamation of the organometallic ferrocene unit and the $\alpha$ aminocresol scaffold. The compounds pursued in the study exhibited higher toxicity towards the susceptible (3D7) and resistant (Dd2) strains of the Plasmodium falciparum parasite than the human HCC70 triple-negative breast cancer cell line. Indication of cross-resistance was absent for the compounds evaluated against the multi-resistant Dd2 strain. The compounds show a dual mode of action involving hemozoin inhibition and DNA interaction via minor groove binding. Lastly, compound 9a, exhibited preferential binding for the plasmodial DNA isolated from 3D7 P. falciparum trophozoites over the mammalian calf thymus DNA, thereby substantiating the enhanced antimalarial activity. The presented research demonstrates the strategy of incorporating organometallic complexes into known biologically active organic scaffolds as a viable avenue to fashion novel multi-modal compounds with potential to counter drug resistance development.
\end{abstract}




\section{INTRODUCTION}

The development of resistance to clinical drugs by diseases is a grave concern that is threatening the outlook of current medicines as effective treatments in modern drug discovery and it requires innovative strategies to address. In cancer, clinical resistance develops when malignant tumour cells undergo changes at genomic and biochemical levels to counteract the effects of an administered anticancer drug. Various hypotheses explaining the processes underpinning the mechanisms that promote anticancer resistance have been proposed and are extensively presented in literature. ${ }^{[1-2]}$ Succinct reviews by Housman et al. and Nikolaou et al. on cancer clinical resistance comprehensively summarize the six common mechanisms leading to development of tumoral drug resistance, of which metabolic drug deactivation and drug efflux by transmembrane proteins of cancer cells are the most prevalent. ${ }^{[3-4]}$ Similarly, antimalarial drug resistance predominantly involves drug efflux and alteration of the therapeutic biomolecular target, whereby the effectiveness of the drug molecule is diminished through its accelerated removal from the active site and reduced affinity for the therapeutic target, respectively. ${ }^{[5-6]}$ This is best demonstrated by the case of chloroquine resistance. The development of chloroquine resistance is postulated to be caused by altered transmembrane proteins of the parasite's digestive vacuole (DV), i.e., the active site where the drug inhibits hemozoin formation, in a manner that limits the accumulation of drug molecules in the DV due to expedited drug efflux, thus, waning its efficacy. ${ }^{[7-8]}$ The challenges posed by both cancer and malarial clinical resistance present a pressing need to search for innovative bioactive molecules with potential to overcome clinical resistance.

Currently, prevailing wisdom dictates that drug candidates eliciting dual or multiple modes of action, for instance; by targeting different biological targets, may overcome or, at the very least, slow down the process of clinical resistance development. ${ }^{[9]}$ To introduce mechanistic diversity into drug molecules, the hybridization approach is gaining attention in contemporary drug 
discovery by merging structurally and mechanistically distinct pharmacophoric units into a single, multi-targeting molecule possessing polypharmacophoric moieties. ${ }^{[10-11]}$ Particularly, the incorporation of organometallic units into bioactive organic drug scaffolds is touted as a promising strategy to produce novel bioactive agents with multiple modes of action. ${ }^{[12-13]}$ Mechanistically, this is due to the fact that organometallic units such as ferrocene possess desirable medicinal attributes, including high lipophilicity and reversible redox character as well as peculiar modalities, that become engendered into the resulting hybrid molecule, leading to the attainment of multitargeting agents. ${ }^{[12-14]}$ Moreover, the next generation antimalarial drug ferroquine, a chloroquinoline-ferrocene conjugate, is a promising candidate for cancer repositioning possessing better efficacy against prostate cancer cell lines than its parental compound, chloroquine, by targeting autophagy and lysosomal function. ${ }^{[15]}$ Recently, the research teams of Cohen and Metzler-Nolte reported the first library of small, threedimensional (3D) metallofragments, which included ferrocene, that showed significant inhibitory activity against a selection of therapeutic targets that are relevant in cancer (Hsp90), viral $\left(\mathrm{PA}_{\mathrm{N}}\right)$ malignancies and bacterial (NDM-1) infections. ${ }^{[16]}$ This seminal work accentuates the medicinal potential of metal-based compounds. Furthermore, the intrinsic 3D shape of organometallic units is hypothesized to facilitate the binding capacity of these molecular fragments to $3 \mathrm{D}$ spaces in biological receptors better than the conventional predominantly $2 \mathrm{D}$ organic molecules due to improved structural affinity. ${ }^{[16-17]}$

The $\alpha$-aminocresols belong to a class of small phenolic compounds with proven biological activity going as far back as 1946 (Figure 1). ${ }^{[18]}$ Burkhalter and co-workers were among the first to investigate the antimalarial efficacy of $\alpha$-amino- $o$-cresols of the type represented by the parental structure 1, resulting in the identification of hit compound $\mathbf{2}$ with substantial in vivo antimalarial activity in avian models. ${ }^{[18]}$ Subsequently, Schmidt and Crosby demonstrated that biphenyl $\alpha$-amino- $o$-cresol (3) reduced the burden of malaria in infected monkeys. ${ }^{[19]}$ 
Additionally, $\alpha$-aminocresols have attracted renewed research interest in the recent years as antimalarial agents. ${ }^{[20-21]}$ By conjugating the adamantane motif to the $\alpha$-aminocresol scaffold, Chinnapattu et al. generated a series of adamantane aminomethylphenols (4) with 3D geometry possessing impressive plasmocidal activity against chemosusceptible (NF54) and multidrugresistant (K1) Plasmodium falciparum strains in the nanomolar range. ${ }^{[20]}$ Similarly, Chibale and co-workers incorporated the $\alpha$-aminocresol moiety into the benzimidazole scaffold to produce $\alpha$-aminocresol-benzimidazole conjugates $(\mathbf{5})$ that were active against the same strains of the malaria parasite. ${ }^{[21]}$ Several $\alpha$-aminocresol derivatives are featured in the Open-Access Box of Medicines for Malaria Venture (MMV) as important structural motifs for investigation and development in antimalarial drug research. ${ }^{[22]}$ Despite these successes, there are no accounts of organometallic derivatives of the $\alpha$-amino- $o$-cresol scaffold presented in literature to our knowledge.<smiles>[R][R]1ccc(O)c(CN([R])[R])c1</smiles><smiles>CC(C)(C)NCc1cc(C(C)(C)C)c(-c2ccc(Cl)cc2)cc1O</smiles>

3<smiles>CN(C)Cc1ccc(C(C)(C)CC(C)(C)C)cc1O</smiles><smiles>[R]c1ccc(CNCC23CC4CC(CC(C4)C2)C3)c(O)c1</smiles>

4<smiles>[R]c1ccc(O)c(CN(CC)CCNc2nc3ccccc3[nH]2)c1</smiles>

5

Figure 1 Chemical structures of $\alpha$-aminocresol with antimalarial activity. 
Previously, we reported the medicinal potential of ferrocenyl 1,3-benzoxazines as multi-active agents possessing in vitro antiproliferative, antiplasmodial and antitrypanosomal efficacy. ${ }^{[23]}$ Our attempts to synthesize ferrocenyl 1,3-benzoxazine 8 by Mannich condensation of 6bromophenol (6) with ferrocenyl amine 7a and paraformaldehyde led to concomitant formation of the $\alpha$-aminocresol side product $9 \mathbf{a}$, which displayed comparable anticancer and antimalarial potencies to the targeted benzoxazine product (8) when screened for biological activity (Scheme 1).

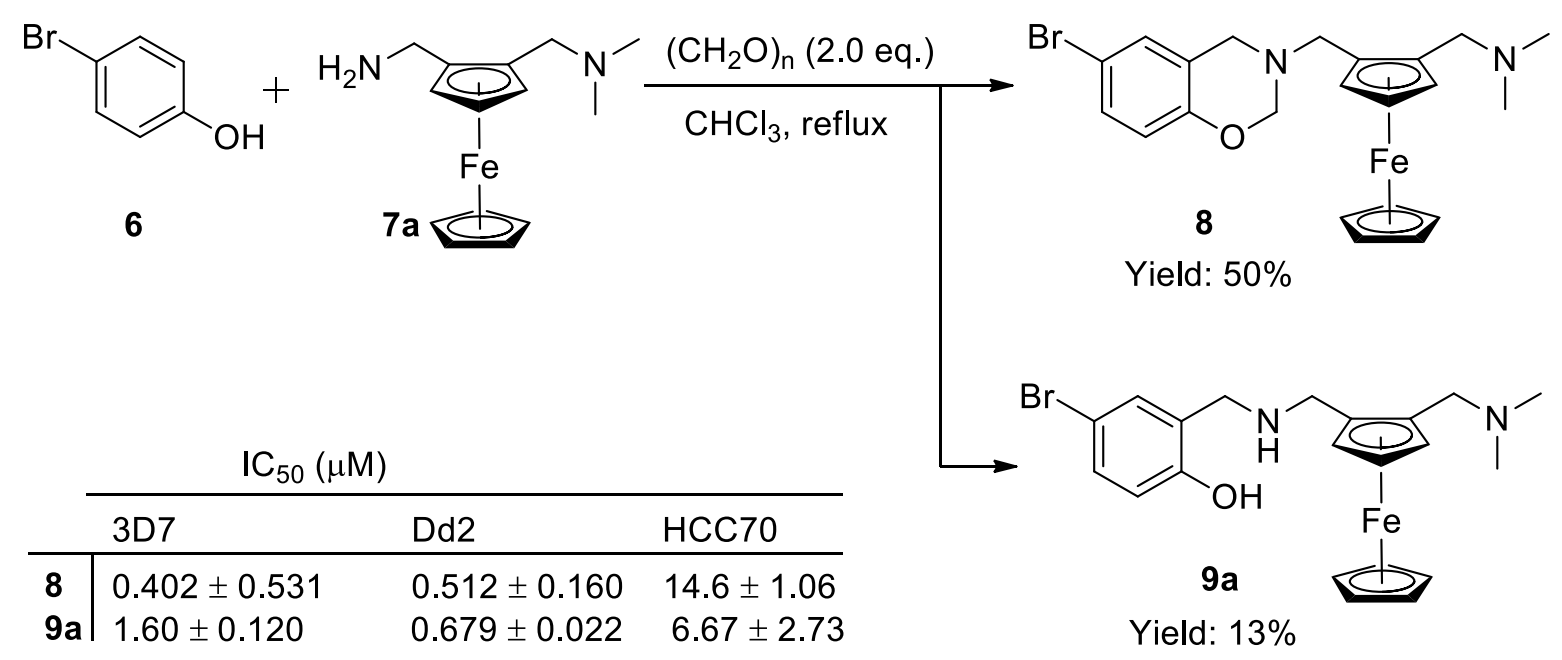

Scheme 1 Synthesis of ferrocenyl 1,3-benzoxazine 8 leading to concomitant formation of ferrocenyl $\alpha$-aminocresol 9a presented with the corresponding biological efficacies $\left(\mathrm{IC}_{50}\right.$ values) of the compounds.

Inspired by these observations and the biological potential of the $\alpha$-aminocresol scaffold reported in literature together with the pharmacological benefits of incorporating the organometallic ferrocene unit into bioactive organic compounds, the current study explores the in vitro anticancer and antimalarial activity of ferrocenyl $\alpha$-amino- $o$-cresol derivatives. Furthermore, investigation of the pursued compounds for hemozoin inhibitory activity, which is a therapeutic target of choice for several antimalarial compounds, and DNA binding affinity, 
both experimentally and by in silico docking simulations, suggested that the compounds likely exhibit biological activity by targeting hemozoin formation and DNA alkylation.

\section{RESULTS AND DISCUSSION}

\section{Synthesis}

In order to determine the pharmacological profile of ferrocenyl $\alpha$-aminocresols, ferrocenyl amine 7a and its less basic congener $7 \mathbf{b}$ lacking the protonatable $\mathrm{CH}_{2} \mathrm{NMe}_{2}$ side chain were synthesized according to methods reported in literature. ${ }^{[24]}$ The basic ferrocenyl $\mathrm{CH}_{2} \mathrm{NMe}_{2}$ moiety is known to enhance the antiplasmodial activity of ferrocene-based compounds. ${ }^{[23-25]}$ Thus, it was considered prudent to synthesize both $\alpha$-aminocresol analogues endowed with and devoid of this functionality to provide insights into the pharmacological effects of modifying the ferrocene unit on the biological activity of the resultant compounds. To avoid possible formation of the benzoxazine product, the target ferrocenyl $\alpha$-aminocresol derivatives were assembled by reductive amination of substituted benzaldehydes (10a-h) with ferrocenyl amines 7a-b using sodium borohydride as the reductant to exclusively yield the desired products. ${ }^{[26]}$ Briefly, a suspension of a substituted benzaldehyde 10a-h and amine 7a-b in ethanol was refluxed for $4-5$ hours to produce an imine intermediate in situ that was subsequently subjected to reduction with sodium borohydride to furnish the desired compounds $\mathbf{9 a - m}$ in moderate to excellent yields following a simple acid-base workup (Scheme 2). ${ }^{[26]}$ The amine 7b lacking the $\mathrm{CH}_{2} \mathrm{NMe}_{2}$ side chain on the ferrocene unit effected higher product yields than amine 7a endowed with this moiety, meanwhile the nature of the benzene substituents $\left(\mathrm{R}^{1}\right)$ did not seem to have an obvious influence on the product yields. For instance, despite having the same benzene substituents $\left(\mathrm{R}^{1}=4-\mathrm{Br}, 6-\mathrm{NO}_{2}\right)$, compound $\mathbf{9 m}$ prepared from amine $\mathbf{7 b}$ was achieved at $82 \%$ yield compared to its ferrocenyl $\mathrm{CH}_{2} \mathrm{NMe}_{2}$ congener $\mathbf{9 h}$ synthesized from amine $7 \mathbf{a}$ with a yield of $23 \%$. 
<smiles>O=CC1=C(O)C=C[R1]C=C1</smiles>

$10 \mathrm{a}: \mathrm{R}^{1}=\mathrm{Br}$

$10 b: R^{1}=4-M e$

$10 \mathrm{c}: \mathrm{R}^{1}=4-\mathrm{NO}_{2}$

$10 d: R^{1}=H$

$10 \mathrm{e}: \mathrm{R}^{1}=6-\mathrm{OMe}$

10f: $: \mathrm{R}^{1}=6-\mathrm{NO}_{2}$

$10 \mathrm{~g}: \mathrm{R}^{1}=4,6-\mathrm{Br}$

$10 \mathrm{~h}: \mathrm{R}^{1}=4-\mathrm{Br}, 6-\mathrm{NO}_{2}$

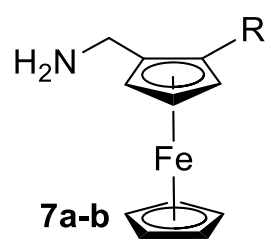

7a: $\mathrm{R}=\mathrm{CH}_{2} \mathrm{NMe}_{2}$

7b: $\mathrm{R}=\mathrm{H}$

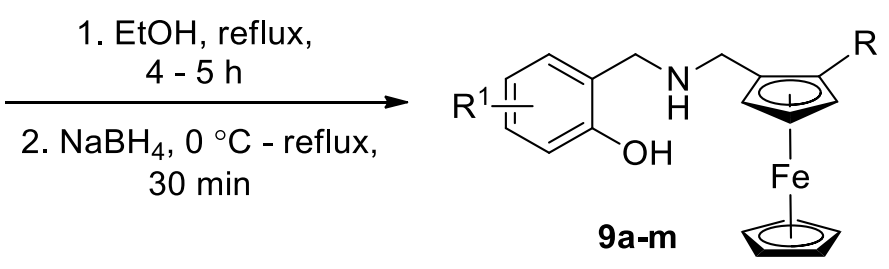

\begin{tabular}{|c|c|c|}
\hline & $\mathrm{R}^{1}$ & Isolated yield (\%) \\
\hline \multirow{8}{*}{$\mathrm{R}=\mathrm{CH}_{2} \mathrm{NMe}_{2}-$} & $9 a: 4-B r$ & 41 \\
\hline & $9 b: 4-\mathrm{Me}$ & 38 \\
\hline & $9 c: 4-\mathrm{NO}_{2}$ & 35 \\
\hline & 9d : H & 63 \\
\hline & 9e : 6-OMe & 76 \\
\hline & 9f : $6-\mathrm{NO}_{2}$ & 38 \\
\hline & $\mathbf{9 g}: 4,6-\mathrm{Br}$ & 43 \\
\hline & $9 \mathrm{~h}: 4-\mathrm{Br}, 6-\mathrm{NO}_{2}$ & 23 \\
\hline \multirow{5}{*}{$\mathrm{R}=\mathrm{H}^{-}$} & $9 \mathrm{i}: \mathrm{H}$ & 98 \\
\hline & 9j : 4-Br & 97 \\
\hline & $9 \mathbf{k}: 6-\mathrm{NO}_{2}$ & 96 \\
\hline & 9I : 4,6-Br & 71 \\
\hline & $9 \mathrm{~m}: 4-\mathrm{Br}, 6-\mathrm{NO}_{2}$ & 82 \\
\hline
\end{tabular}

Scheme 2 Synthesis of target ferrocenyl $\alpha$-aminocresols by reductive amination.

The biological activity of $\alpha$-aminocresols is attributed to the molecular architecture of the scaffold. Particularly, the exhibition of the internal hydrogen bond between the phenolic hydroxyl and amino nitrogen groups is crucial for the antiplasmodial activity of $\alpha$ aminocresols. ${ }^{[21]}$ Additionally, Chinnapattu et al. found that constraining the rotatability of the bond between the $\alpha$-carbon and the amino nitrogen atom by introducing an amide bond led to a decrease in activity of the resulting compounds. ${ }^{[20]}$ Therefore, in order to comprehensively elucidate the structure-activity relationship (SAR) profile of the pursued ferrocenyl $\alpha$ aminocresols, the phenolic hydroxy group $(\mathrm{OH})$ and the rotatable $\alpha-\mathrm{C}-\mathrm{NH}$ bond were modified by synthesizing non-phenolic benzylamines 12a-d and salicylamides 14a-g as non-rotatable aminocresol congeners, respectively.

The non-phenolic benzylamines 12a-c were prepared by replacing the phenolic $\mathrm{OH}$ group with substituents; $\mathrm{H}, \mathrm{OMe}$, and $\mathrm{NO}_{2}$, from appropriate benzaldehydes 11a-c and ferrocenyl amine 
7a following the synthetic route in Scheme 3. The 2-aminobenzylamine 12d was obtained via zinc-catalyzed reduction of 2-nitrobenzylamine $\mathbf{1 2 c}$ in the presence of ammonium chloride. ${ }^{\text {[27] }}$ We envisaged that substituting the phenolic $\mathrm{OH}$ group of the $\alpha$-amino- $o$-cresol scaffold for these functional groups would disrupt the intramolecular hydrogen bonding in the resulting compounds and provide understanding of the pharmacological significance of this molecular feature.<smiles>[R]c1ccccc1C=O</smiles>

$11 \mathrm{a}: \mathrm{R}=\mathrm{H}$

$11 \mathrm{~b}: \mathrm{R}=\mathrm{OMe}$

$11 \mathrm{c}: \mathrm{R}=\mathrm{NO}_{2}$

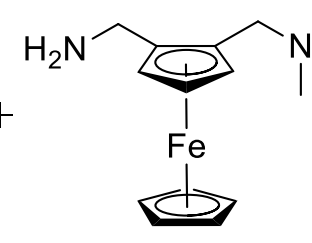

$7 a$
$12 a-d$

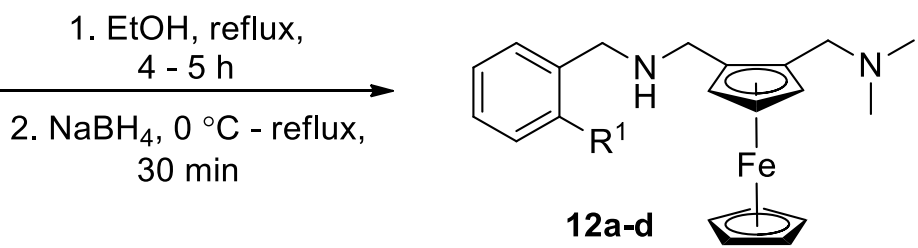

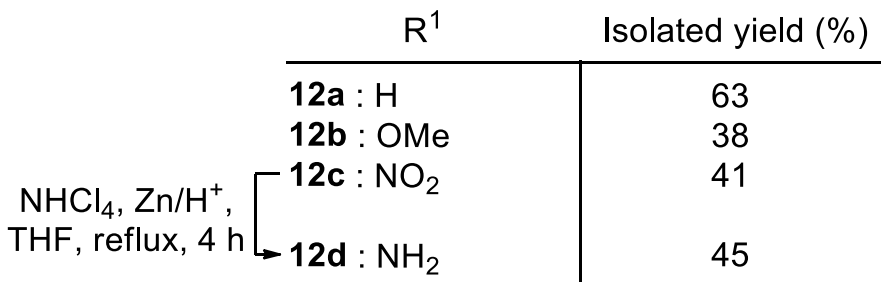

Scheme 3 Synthesis of non-phenolic ferrocenyl benzylamines 12a-d.

Similarly, salicylic acids 13a-e and ferrocenyl amines 7a-b were coupled by $N, N^{\prime}-$ dicyclohexylcarbodiimide (DCC) amidation in one step under microwave irradiation in pyridine (Scheme 4). ${ }^{[28]}$ To further probe the biological effect of modifying the benzene ring, ferrocenyl nicotinamide $14 \mathbf{f}$ containing a pyridine ring in lieu of the benzene ring was synthesized from nicotinic acid 13e and ferrocenyl amine 7a. Moreover, it was considered worthwhile to investigate the influence of the phenolic $\mathrm{OH}$ group within this series by exchanging it with a more acidic thiol functionality (SH). Thus, a thiol congener of salicylamide $\mathbf{1 4 f}$ was synthesized by reacting thiosalicylic acid $\mathbf{1 3 f}$ and ferrocenyl amine $\mathbf{7 b}$ to produce thiosalicylamide $\mathbf{1 4 g}$ featuring the SH group in position 2 (Scheme 4). 


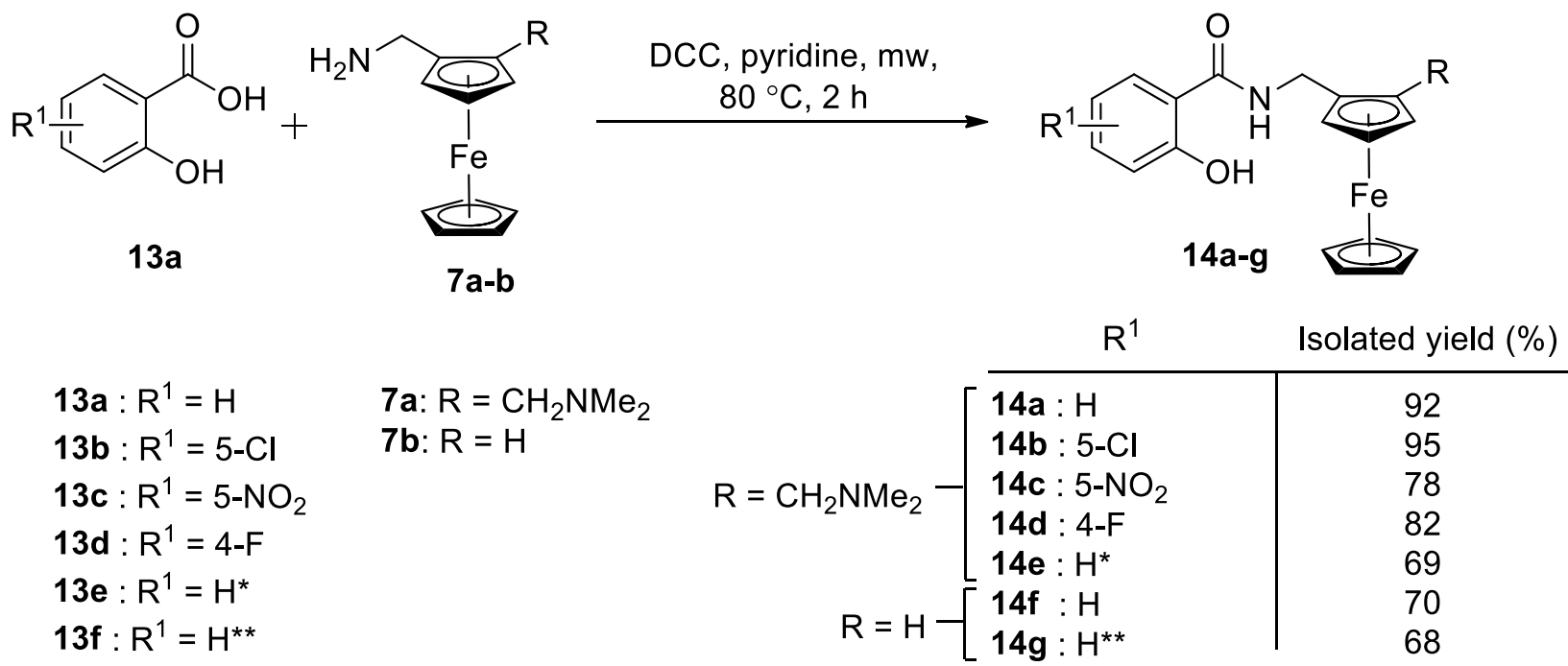

Scheme 4 Synthesis of ferrocenyl salicylamide 14a-g. 13e: $\mathrm{R}^{1}=\mathrm{H}^{*}$, 2-hydroxynicotinic acid. 13f: $\mathrm{R}^{1}=\mathrm{H}^{* *}$, thiosalicylic acid. 14e: $\mathrm{R}^{1}=\mathrm{H}^{*}$, 2-hydroxynicotinamide product synthesized from 13e. 14g: $\mathrm{R}^{1}=\mathrm{H}^{* *}$, thiosalicylamide product synthesized from $\mathbf{1 3 f}$.

The structural identities of all the synthesized compounds were confirmed by common spectroscopic techniques: nuclear magnetic resonance $\left({ }^{1} \mathrm{H}\right.$ and $\left.{ }^{13} \mathrm{C} \mathrm{NMR}\right)$ and high-resolution mass spectrometry (HRMS). The full spectral data of all the compounds are provided in the experimental section and Supporting Information of this paper. For all the compounds, the most notable characteristics of their ${ }^{1} \mathrm{H}$ NMR spectra was the appearance of the phenolic protons in the aromatic region and the distinctive ferrocene signals at $\delta 4.50-4.00 \mathrm{ppm}$. The ferrocene signals were observed as three broad singlets for the $\mathrm{CH}_{2} \mathrm{NMe}_{2}$ ferrocenyl compounds (9a-h, 12a-d and 14a-e) each integrating for one proton or as two $2 \mathrm{H}$ triplets in the case of plain ferrocenyl congeners (9i-m and $\mathbf{1 4 f - g}$ ) and a $5 \mathrm{H}$ singlet corresponding to the top and bottom cyclopentadienyl rings, respectively. Also noteworthy was the splitting of the two ferrocene-appended methylene $\left(\mathrm{CH}_{2}\right)$ protons that were both observed as two $1 \mathrm{H}$ doublets due to geminal coupling $(J$-coupling constants: $12.0-13.6 \mathrm{~Hz})$ and planar chirality of the ferrocene unit for the $\mathrm{CH}_{2} \mathrm{NMe}_{2}$-containing derivatives (9a-h, 12a-d and 14a-e). ${ }^{[24]}$ The purity of the compounds was determined by HPLC (see Supporting Information) and the values were 
uncorrected. The HPLC purity, which was at least $80 \%$ in all instances, together with the clean ${ }^{1} \mathrm{H}$ and ${ }^{13} \mathrm{C}$ NMR spectra of the compounds were convincing to suggest adequate purity to proceed with biological evaluation assays. 


\section{Biological evaluation}

The synthesized ferrocenyl $\alpha$-aminocresols were evaluated for potential antiplasmodial and anticancer activity in vitro against the chloroquine-sensitive (CQS) 3D7 P. falciparum strain and human HCC70 triple-negative breast cancer cell line. A selection of the compounds was also assessed on the chloroquine-resistant (CQR) Dd2 P. falciparum strain. Furthermore, to establish the possible mode of action of the ferrocenyl $\alpha$-aminocresols, representative compounds from each series showing the most promising activity were studied for DNA binding affinity and hemozoin inhibition in terms of the $\beta$-hematin binding assay employing spectrophotometric techniques from literature. ${ }^{[29-30]}$ The findings of the mechanistic studies were corroborated by in silico docking simulations of the tested compounds against a B-DNA structure and a homology model of the hemozoin crystal using AutoDock Vina (v1.5.6, 2014).$^{[31]}$

\section{In vitro antiplasmodial activity}

The antiplasmodial activity of the compounds was determined on the chloroquine-sensitive (CQS) 3D7 and chloroquine-resistant (CQR) Dd2 P. falciparum strains by at least two independent replicates. In each experiment, varying concentrations of the test compound were incubated with the parasites for 48 hours and the activity was determined as the mean of effective concentration required to reduce $P$. falciparum parasitemia (assessed by Plasmodium lactate dehydrogenase activity) 50\%, i.e., half-maximal concentration ( $\mathrm{IC}_{50}$ value). Known antimalarial drugs, chloroquine (CQ) and artemisinin (Art) were assessed similarly to the test compounds and used as positive controls in the biological evaluation assays. The results of the antiplasmodial screening assay are presented in Table $\mathbf{1}$. The $\mathrm{IC}_{50}$ values are reported as a mean value obtained from triplicate experiments for each compound with the margin of error estimated by the standard deviation $( \pm \mathrm{SD})$. 
Table 1 In vitro antiplasmodial activity of ferrocenyl $\alpha$-aminocresol derivatives evaluated against the CQS 3D7 and CQR Dd2 P. falciparum strains.

\begin{tabular}{|c|c|c|c|c|c|c|}
\hline & $9 a-m$, & a-d & & $\underbrace{\mathrm{N}}_{14 \mathrm{a}-\mathrm{g}}$ & $\mathrm{Fe}$ & \\
\hline \multirow[t]{2}{*}{ Compound } & \multirow[t]{2}{*}{$\mathbf{R}$} & \multirow[t]{2}{*}{$\mathbf{R}^{1}$} & \multirow[t]{2}{*}{$\mathbf{R}^{2}$} & \multicolumn{2}{|c|}{$\mathrm{IC}_{50}(\boldsymbol{\mu M})$} & \multirow[t]{2}{*}{ R.I. ${ }^{[a]}$} \\
\hline & & & & $3 \mathrm{D} 7$ & $\mathrm{Dd} 2$ & \\
\hline $9 \mathbf{a}$ & $\mathrm{CH}_{2} \mathrm{NMe}_{2}$ & $4-\mathrm{Br}$ & $\mathrm{OH}$ & $1.60 \pm 0.04$ & $0.69 \pm 0.02$ & 0.4 \\
\hline $9 b$ & $\mathrm{CH}_{2} \mathrm{NMe}_{2}$ & 4-Me & $\mathrm{OH}$ & $0.98 \pm 0.10$ & nd & - \\
\hline $9 c$ & $\mathrm{CH}_{2} \mathrm{NMe}_{2}$ & $4-\mathrm{NO}_{2}$ & $\mathrm{OH}$ & $1.88 \pm 0.10$ & nd & - \\
\hline $9 d$ & $\mathrm{CH}_{2} \mathrm{NMe}_{2}$ & $\mathrm{H}$ & $\mathrm{OH}$ & $2.23 \pm 0.12$ & nd & - \\
\hline $9 e$ & $\mathrm{CH}_{2} \mathrm{NMe}_{2}$ & 6-OMe & $\mathrm{OH}$ & $4.70 \pm 0.25$ & $6.61 \pm 1.74$ & 1.4 \\
\hline $9 f$ & $\mathrm{CH}_{2} \mathrm{NMe}_{2}$ & $6-\mathrm{NO}_{2}$ & $\mathrm{OH}$ & $12.3 \pm 0.24$ & nd & - \\
\hline $9 \mathrm{~g}$ & $\mathrm{CH}_{2} \mathrm{NMe}_{2}$ & 4,6-Br & $\mathrm{OH}$ & $1.10 \pm 0.14$ & $0.94 \pm 0.08$ & 0.9 \\
\hline $9 h$ & $\mathrm{CH}_{2} \mathrm{NMe}_{2}$ & $4-\mathrm{Br}, 6-\mathrm{NO}_{2}$ & $\mathrm{OH}$ & $5.52 \pm 0.30$ & nd & - \\
\hline $9 \mathbf{i}$ & $\mathrm{H}$ & $\mathrm{H}$ & $\mathrm{OH}$ & nd & nd & - \\
\hline 9j & $\mathrm{H}$ & $4-\mathrm{Br}$ & $\mathrm{OH}$ & $2.30 \pm 0.28$ & $1.68 \pm 0.28$ & 0.7 \\
\hline $9 \mathbf{k}$ & $\mathrm{H}$ & $6-\mathrm{NO}_{2}$ & $\mathrm{OH}$ & nd & nd & - \\
\hline 91 & $\mathrm{H}$ & $4,6-\mathrm{Br}$ & $\mathrm{OH}$ & $4.30 \pm 0.03$ & $3.87 \pm 0.21$ & 0.9 \\
\hline $9 m$ & $\mathrm{H}$ & $4-\mathrm{Br}, 6-\mathrm{NO}_{2}$ & $\mathrm{OH}$ & nd & $>10$ & - \\
\hline $12 \mathbf{a}$ & $\mathrm{CH}_{2} \mathrm{NMe}_{2}$ & $\mathrm{H}$ & $\mathrm{H}$ & $2.99 \pm 0.30$ & nd & - \\
\hline $12 b$ & $\mathrm{CH}_{2} \mathrm{NMe}_{2}$ & $\mathrm{H}$ & $\mathrm{OMe}$ & $4.78 \pm 0.23$ & nd & - \\
\hline $12 \mathrm{c}$ & $\mathrm{CH}_{2} \mathrm{NMe}_{2}$ & $\mathrm{H}$ & $\mathrm{NO}_{2}$ & $3.13 \pm 0.39$ & nd & - \\
\hline 12d & $\mathrm{CH}_{2} \mathrm{NMe}_{2}$ & $\mathrm{H}$ & $\mathrm{NH}_{2}$ & $4.49 \pm 0.39$ & nd & - \\
\hline $14 \mathbf{a}$ & $\mathrm{CH}_{2} \mathrm{NMe}_{2}$ & $\mathrm{H}$ & $\mathrm{OH}$ & $9.64 \pm 1.17$ & nd & - \\
\hline $14 b$ & $\mathrm{CH}_{2} \mathrm{NMe}_{2}$ & $5-\mathrm{Cl}$ & $\mathrm{OH}$ & $20.9 \pm 0.85$ & nd & - \\
\hline $14 c$ & $\mathrm{CH}_{2} \mathrm{NMe}_{2}$ & $5-\mathrm{NO}_{2}$ & $\mathrm{OH}$ & $12.8 \pm 0.85$ & nd & - \\
\hline $14 d$ & $\mathrm{CH}_{2} \mathrm{NMe}_{2}$ & $4-\mathrm{F}$ & $\mathrm{OH}$ & na & nd & - \\
\hline $14 \mathrm{e}^{[\mathrm{b}]}$ & $\mathrm{CH}_{2} \mathrm{NMe}_{2}$ & $\mathrm{H}$ & $\mathrm{OH}$ & $21.9 \pm 1.47$ & nd & - \\
\hline $14 f$ & $\mathrm{H}$ & $\mathrm{H}$ & $\mathrm{OH}$ & na & nd & - \\
\hline $14 g^{[c]}$ & $\mathrm{H}$ & $\mathrm{H}$ & $\mathrm{SH}$ & na & nd & - \\
\hline CQ & - & - & - & $0.03 \pm 0.0$ & $0.188 \pm 0.07$ & 6.3 \\
\hline Art & - & - & - & - & $0.006 \pm 0.0$ & - \\
\hline
\end{tabular}

R.I. ${ }^{[a]}=$ resistance index, ratio of activity against the resistant strain to activity against the sensitive strain, i.e., $\mathrm{IC}_{50}[\mathrm{Dd} 2] / \mathrm{IC}_{50}[3 \mathrm{D} 7] . \mathbf{1 4}^{[\mathrm{b}]}=$ nicotinamide congener. $\mathbf{1 4 g}^{[\mathrm{c}]}=$ thiosalicylamide analogue. $\mathrm{nd}=$ not determined. na $=$ not active. 
From the antiplasmodial evaluation results, the $\alpha$-amino- $o$-cresol series $9 \mathbf{a}-\mathbf{m}$ was generally the most potent against the 3D7 P. falciparum strain among the screened compounds followed by benzylamines 12a-d and salicylamides 14a-g, respectively. In all cases the basic $\mathrm{CH}_{2} \mathrm{NMe}_{2}$ ferrocenyl derivatives were more potent than their less basic analogues devoid of this motif. This observation corroborates the favourable pharmacological effects of attaching the $\mathrm{CH}_{2} \mathrm{NMe}_{2}$ moiety to the ferrocene unit as observed in previous studies. ${ }^{[23-24]}$

For the $\alpha$-amino-o-cresol series 9a-m, the electron-donating groups (EDGs) on the benzene ring appeared to impart higher efficacy with $\mathrm{Me}>\mathrm{Br}>\mathrm{NO}_{2}$ irrespective of the position of substitution on the benzene ring (Table 1). For instance, compounds bearing the electronreleasing methyl and methoxy groups (9b and 9e) exhibited higher activity than their nitrocontaining counterparts (9c and 9f) by approximately 2-fold. Aminocresol $\mathbf{9 b}$ containing the electron-donating methyl group emerged as the most potent compound against the CQS 3D7 strain in the entire series with an $\mathrm{IC}_{50}$ value of $0.98 \pm 0.10 \mu \mathrm{M}$ followed by compound containing electron-withdrawing groups (EWGs): $\mathrm{Br}$ (9a) and $\mathrm{NO}_{2}$ (9d), respectively. Substitution at C-4 (9a-d) was more favourable for antiplasmodial activity compared to position 6 (9e-f), while simultaneous functionalisation of these positions (9g-h) was only tolerated for efficacy. As before, of the six compounds from the aminocresol series tested against the Dd2 multi-resistant strain, the brominated compounds $(\mathbf{9 a}$ and $\mathbf{9 g})$ with the basic $\mathrm{CH}_{2} \mathrm{NMe}_{2}$ moiety appended on the ferrocenyl unit were the most active with comparable $\mathrm{IC}_{50}$ values in the sub-micromolar range, whereas their less basic congeners devoid of this moiety (9j and 91) displayed activity in the low micro-molar range (Table 1). As with the susceptible 3D7 strain, substitution at C-6 (ortho-position) proved detrimental for the antiplasmodial activity against the resistant Dd2 strain compared to C-4 (para-position). This is illustrated by the inferior activity of the 6-OMe aminocresol 9f $\left(\mathrm{IC}_{50}=6.61 \pm 1.74 \mu \mathrm{M}\right)$ with respect to the derivatives containing at least one $\mathrm{Br}$ group on $\mathrm{C}-4(\mathbf{9 a}, \mathbf{9 g}, \mathbf{9 j}$ and $9 \mathbf{l})$ (Table 1). 
The antiplasmodial activity of the $\alpha$-aminocresol 9d was reduced upon removal (12a) and replacement of the phenolic $\mathrm{OH}$ group with the $\mathrm{OMe}(\mathbf{1 2 b}), \mathrm{NO}_{2}(\mathbf{1 2 c})$ and $\mathrm{NH}_{2}(\mathbf{1 2 d})$ functionalities by almost 2-fold (Table 1), highlighting the pharmacological significance of this structural feature. The reduction in activity due to the replacement of the $\mathrm{OH}$ group, could be explained by the influence of the internal hydrogen bond $(\mathrm{O}-\mathrm{H} \cdots \mathrm{N}-\mathrm{H})$ on the antimalarial activity of $\alpha$-aminocresols. Indeed, the presence of the intramolecular hydrogen bond is known to augment the activity of antimalarial agents. ${ }^{[21,32-34]}$ The intramolecular hydrogen bond in the $\alpha$-aminocresol side chain of 4-aminoquinoline antimalarial drugs, amodiaquine and isodiaquine, is believed to be crucial for their activity. ${ }^{[32]}$ Moreover, Madrid et al. demonstrated that incorporating the intramolecular hydrogen bond of $\alpha$-aminocresol into the side chain of 4aminoquinolines enhances their activity against the drug-resistant $P$. falciparum strains. ${ }^{[33]}$ Thus, the observed reduction in antiplasmodial activity of the ferrocenyl non-cresol benzylamine derivatives 12a-d seems to be a result of removing (12a) and replacing the acidic, strong hydrogen bond donor, i.e., phenolic $\mathrm{OH}$ group (9d), with hydrogen bond acceptors $\mathrm{OMe}$ (12b) and $\mathrm{NO}_{2}(\mathbf{1 2 c})$ and basic donor $\mathrm{NH}_{2}(\mathbf{1 2 d})$, leading to reduced activity due to formation of a weaker hydrogen bond between these groups and the aliphatic NH group.

Constraining the rotation of the $\mathrm{C}-\mathrm{N}$ bond between the $\alpha$-carbon and $\mathrm{NH}$ group was unfavourable for antiplasmodial activity as demonstrated by the substantially inferior potency of ferrocenyl salicylamides $\mathbf{1 4 a - g}$ relative to $\alpha$-aminocresols $\mathbf{9 a - m}$ and non-cresol benzylamines 12a-d (Table 2). This is further supported by the findings of Chinnapattu et al. in which they found that incorporating the amide bond between the $\alpha$-carbon and $\mathrm{NH}$ group in adamantane-based aminocresols caused their antimalarial potency to plummet. ${ }^{[20]}$ Within the salicylamide series, the unsubstituted analogue $\mathbf{1 4 a}$ was the most active, while the 5-Cl (14b) and $5-\mathrm{NO}_{2}(\mathbf{1 4 c})$ variants substituted para with respect to the $\mathrm{OH}$ group were less active. Activity was lost upon substitution of the fluorine atom in the meta-position relative to $\mathrm{OH}$, 
emphasizing the pharmacological significance of para-substitution as previously observed for the aminocresols 9a-m (Table 1). The nicotinamide congener 14e was half as potent as the parental salicylamide 14a. This suggests that replacing the benzene ring with the pyridine unit is undesirable for antiplasmodial activity. Lastly, salicylamide $\mathbf{1 4 f}$ and thiosalicyalmide $\mathbf{1 4 g}$ lacking the basic $\mathrm{CH}_{2} \mathrm{NMe}_{2}$ ferrocenyl chain were ineffective at inhibiting the growth of the 3D7 strain at the tested concentrations.

To investigate the selectivity of the compounds between the $P$. falciparum parasite and human cells, HeLa cells were employed to assess the general toxicity of the compounds using a resazurin assay as described in previous studies in literature. ${ }^{[35-36]}$ The compounds were tested at a fixed concentration of $20 \mu \mathrm{M}$ and the results are illustrated in Figure S1 plotted in parallel with the viability of 3D7 P. falciparum parasitaemia. At least $70 \% \mathrm{HeLa}$ cell viability was observed for the majority of compounds at the tested concentration of $20 \mu \mathrm{M}$, implying preferential selectivity for the malaria parasite over mammalian cells.

\section{Antiproliferative activity}

The in vitro anticancer efficacy of a selection of the investigated compounds was determined on the HCC70 triple-negative breast cancer cell line. In a typical procedure, live cells were treated with varying concentrations of test compounds or anticancer drug paclitaxel and then incubated for a period of $48-72$ hours. Antiproliferative activities were determined using the resazurin assay in triplicate and reported as half-maximal inhibitory concentrations, i.e., $\mathrm{IC}_{50}$ values (Table 2). 
Table 2 In vitro antiproliferative activity of ferrocenyl $\alpha$-aminocresol derivatives evaluated against the HCC70 human triple-negative breast cancer cell line.

\begin{tabular}{|c|c|c|c|c|}
\hline & m, 12a-d & $\mathrm{R}^{1} \frac{\sqrt[5]{1}}{4}$ & $\begin{array}{r}\mathrm{H} \\
\mathrm{D} \\
\mathbf{a}-\mathbf{g}\end{array}$ & $R$ \\
\hline \multirow[t]{2}{*}{ Compound } & $\mathbf{R}$ & $\mathbf{R}^{1}$ & $\mathbf{R}^{2}$ & $\mathrm{IC}_{50}(\boldsymbol{\mu M})^{[\mathrm{a}]}$ \\
\hline & & & & HCC70 \\
\hline $9 a$ & $\mathrm{CH}_{2} \mathrm{NMe}_{2}$ & $4-\mathrm{Br}$ & $\mathrm{OH}$ & 6.67 \\
\hline $9 b$ & $\mathrm{CH}_{2} \mathrm{NMe}_{2}$ & 4-Me & $\mathrm{OH}$ & 28.4 \\
\hline $9 h$ & $\mathrm{CH}_{2} \mathrm{NMe}_{2}$ & $4-\mathrm{Br}, 6-\mathrm{NO}_{2}$ & $\mathrm{OH}$ & 56.2 \\
\hline 9l & $\mathrm{H}$ & $4,6-\mathrm{Br}$ & $\mathrm{OH}$ & 24.2 \\
\hline $12 \mathrm{~b}$ & $\mathrm{CH}_{2} \mathrm{NMe}_{2}$ & $\mathrm{H}$ & $\mathrm{OMe}$ & 20.9 \\
\hline Paclitaxel & - & - & - & 0.0025 \\
\hline
\end{tabular}

IC50 $(\boldsymbol{\mu M})^{[\mathrm{a}]}=$ half-maximal inhibitory concentration determined in triplicate, in all cases the standard deviation $( \pm \mathrm{SD})$ was below 2.0.

For all tested compounds, only three $\alpha$-amino-o-cresols (9a, $9 \mathbf{b}$ and $9 \mathbf{h}$ ) carrying the ferrocenyl $\mathrm{CH}_{2} \mathrm{NMe}_{2}$ and the $O$-methyl $\alpha$-amino- $O$-cresol $\mathbf{1 2 b}$ were active against the HCC70 cell line with $\mathrm{IC}_{50}$ values between 6.67 and $56.2 \mu \mathrm{M}$ (Table 2), highlighting the importance of the $\mathrm{CH}_{2} \mathrm{Me}_{2}$ motif as before. Compound 91 lacking the basic ferrocenyl $\mathrm{CH}_{2} \mathrm{NMe}_{2}$ motif was an exception to this observation and exhibited antiproliferative activity with an $\mathrm{IC}_{50}$ value of 24.2 $\mu \mathrm{M}$. All the compounds not presented in Table 2 were non-toxic towards the cell line. Notably, the activity was lost upon removal of the ortho oxygen atom in the $\alpha$-amino- $o$-cresol template (12a). Likewise, rigidifying the $\mathrm{C}-\mathrm{NH}$ bond in salicylamides (14a-f) was detrimental for anticancer activity of the compounds as no activity was observed for these compounds. This corroborates the patterns noted in the biological activity of plasmocidal adamantane-based $\alpha$ amino- $o$-cresols by Chinnapattu et al. ${ }^{[20]}$ 


\section{Mechanistic studies}

Based on the in vitro biological screening results, the investigated compounds exhibited higher selectivity for both the $3 \mathrm{D} 7$ and Dd2 $P$. falciparum parasites over the mammalian HCC70 triple-negative breast cancer cell line. As with the majority of antiplasmodial compounds, particularly 4-aminoquinines, that exert biological activity by targeting the heme detoxification pathway, i.e., hemozoin formation, we envisaged that our $\alpha$-amino- $o$-cresol derivatives might possess a similar ability. ${ }^{[37]}$ Moreover, we previously demonstrated that related Mannich bases, i.e., ferrocenyl 1,3-benzoxazines, exhibited biological activity involving DNA interaction leading to DNA damage. ${ }^{[23]}$ As Mannich base derivatives, we postulated that the investigated $\alpha$-amino- $o$-cresol analogues in the current study would display activity similar to the 1,3 benzoxazines through DNA interaction. ${ }^{[23]}$ Thus, representative compounds from each series showing the most encouraging activity were probed for DNA binding affinity determined by UV-Vis spectroscopic procedures and hemozoin inhibition using the $\beta$-hematin binding assay from literature. ${ }^{[29-30]}$ The obtained results were validated by performing in silico docking simulations of the compounds against a constructed hemozoin crystal model and a B-DNA structure from protein data bank.

\section{$\beta$-Hematin binding assay for hemozoin inhibition}

The inhibition of the hemozoin crystallization pathway is a commonplace mechanism by which most compounds exhibit antimalarial activity. The assay developed by Ncokazi and Egan making use of $\beta$-hematin, a synthetic form of hemozoin, is an invaluable tool in the screening of antimalarial agents for hemozoin inhibition. ${ }^{[30]}$ In the $\beta$-hematin binding assay, a homogeneous suspension of $\beta$-hematin was treated with varying concentrations of representative compounds: $\alpha$-amino- $o$-cresols $9 \mathbf{a}, \mathbf{9 b}$ and $\mathbf{9 j}$, amine 12a and salicylamide 14a, and CQ as a positive control in a 96-well plate. Crystallization of $\beta$-hematin into hemozoin was 
induced by addition of NP-40 detergent into each well followed by a 6-hour incubation at 37 ${ }^{\circ} \mathrm{C}$. The hemozoin inhibition capacity of the compounds was determined by assessing the absorbance of the free heme complex at $405 \mathrm{~nm}$ for each concentration according to the pyridine-ferrichrome method. ${ }^{[38]}$ The results were reported as $\mathrm{IC}_{50}$ values generated by nonlinear regression analysis of a plot of absorbance vs. log [compound concentration] in GraphPad Prism 4.0 (Table 3).

Table 3 Results of the $\beta$-hematin binding assay for hemozoin inhibition and calculated partition coefficients $(C \log \mathrm{P})$.

\begin{tabular}{|ccc|}
\hline Compound & IC $_{\mathbf{5 0}}(\boldsymbol{\mu M})^{[\mathrm{a}]}$ & $\boldsymbol{C l o g}^{[\mathrm{b}]}$ \\
\hline $\mathbf{9 a}$ & $88.7 \pm 1.04$ & 4.67 \\
$\mathbf{9 b}$ & $230.1 \pm 1.08$ & 4.24 \\
$\mathbf{9 j}$ & $81.7 \pm 1.03$ & 4.97 \\
$\mathbf{1 2 a}$ & $>500$ & 3.81 \\
$\mathbf{1 4 a}$ & $194.4 \pm 1.05$ & 3.52 \\
CQ & $328.8 \pm 1.08$ & - \\
\hline $\mathrm{IC}_{50}{ }^{[\mathrm{a}]}=$ concentration of compound required to inhibit crystallization of hematin to
\end{tabular}

$\mathrm{IC}_{50}{ }^{[\mathrm{a}]}=$ concentration of compound required to inhibit crystallization of hematin to hemozoin by half of its initial concentration, the margin of error is reported as the standard error. $C \log \mathrm{P}^{[\mathrm{b}]}=$ calculated partition coefficients, values were calculated according the procedure reported in ref. [39] for $\log \mathrm{P}$ prediction of ferrocenyl compounds (Supporting Information). The prediction does not take into account intramolecular hydrogen bonding effects.

The brominated $\alpha$-amino- $o$-cresols $9 \mathbf{a}$ and $\mathbf{9 j}$ showed the highest binding affinity for $\beta$-hematin as demonstrated by their comparable $\mathrm{IC}_{50}$ values of 88.7 and $81.7 \mu \mathrm{M}$, respectively. Compound 9b bearing the methyl group in place of the bromine had a lower affinity relative to the brominated aminocresols, implying that the bromine atom at C-4 may be conducive for binding to the heme complex. Inhibition of hemozoin was lost upon removal of the phenolic $\mathrm{OH}$ group in compound 12a as suggested by its inferior activity $\left(\mathrm{IC}_{50}>500 \mu \mathrm{M}\right)$. Based on this observation, it was apparent that the intramolecular hydrogen bond in aminocresols is not only 
crucial for the antiplasmodial activity of the compounds but is also associated with their ability to interact with the $P$. falciparum target, hemozoin. The effects of the amide bond were unfavourable for hemozoin inhibitory activity of salicylamide 14a as similarly observed for the antiplasmodial activity. Moreover, it was interesting to note that the observed hemozoin inhibitory activity seemed to be correlated to the lipophilicity of the compounds since derivatives $9 \mathbf{a}$ and $\mathbf{9 j}$ exhibiting the highest binding affinity had higher calculated partition coefficients $(C \log \mathrm{P})$ compared to the less active analogues $\mathbf{9 b}, \mathbf{1 2 a}$ and $\mathbf{1 4 a}$ with lower $C \log \mathrm{P}$ values (Table 3). Overall, these results suggested that hemozoin inhibition is likely one of the mechanisms by which the investigated compounds exert antiplasmodial activity. It is also noteworthy that, with the exception of compound 12a, all the compounds showed superior hemozoin inhibition compared to the standard drug chloroquine.

\section{DNA binding studies}

A majority of Mannich base derivatives such as the $\alpha$-amino- $o$-cresols explored in the current study have high affinity for DNA. ${ }^{[40-41]}$ This was previously demonstrated with structurally related ferrocenyl 1,3-benzoxazines possessing antiproliferative effects through DNA interaction. ${ }^{[23]}$ Based on our previous findings with structurally similar benzoxazines, it seemed justifiable to interrogate the current Mannich bases, i.e., ferrocenyl $\alpha$-amino- $O$-cresol analogues, for DNA binding. Using UV-Vis DNA titration experiments, a fixed concentration of calf thymus DNA was incubated with a concentration range of the test compounds $(\mathbf{9 a}, \mathbf{9 b}$, 9j, 12a and 14a) and the absorbance was monitored at the wavelength of DNA $(260 \mathrm{~nm}) .{ }^{[29,42]}$ A dose-dependent linear hyperchromic shift accompanied by a slight blue-shift $(\sim 2 \mathrm{~nm})$ in the spectral maximum of the test samples indicated positive interaction of the compound with DNA via external forces. ${ }^{[43]}$ Only the $\alpha$-amino-o-cresols $9 \mathbf{9 a}, \mathbf{9 b}$ and $\mathbf{9 j}$ containing the phenolic $\mathrm{OH}$ group and rotatable $\mathrm{C}-\mathrm{NH}$ bond exhibited these effects, while the non-phenolic amine 12a and 
rotationally constrained salicylamide 14a produced no discernible pattern in the spectral shift of their samples (Figure 2A-C).

The data obtained from these results were fitted into the reciprocal guest-host equation (1) relating compound concentration to absorbance to allow quantification of the binding affinity in terms of the binding constant $\left(\mathrm{K}_{\mathrm{b}}\right)$ :

$$
\frac{1}{A_{c}-A_{0}}=\frac{1}{K_{b}\left(A_{\infty}-A_{o}\right)} \times \frac{1}{[C]}+\frac{1}{A_{\infty}-A_{0}}
$$

where $A_{c}$ is absorbance of the DNA sample treated with the compound, $A_{0}$ is the absorbance of the untreated DNA sample, $[C]$ is the concentration of the compound, $K_{b}$ is the binding constant and $A_{\infty}$ is the hypothetical final absorbance of the DNA-compound complex. ${ }^{[29]}$ The reciprocal plots for compounds $\mathbf{9 a}, \mathbf{9 b}$ and $\mathbf{9 j}$ are illustrated in Figures $\mathbf{2 D - F}$.

A

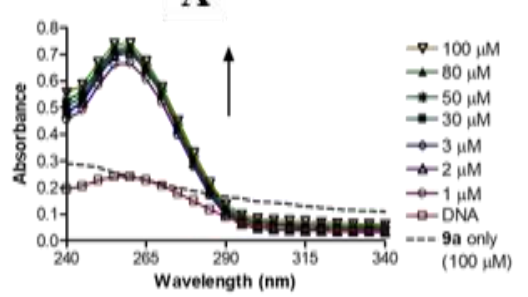

D

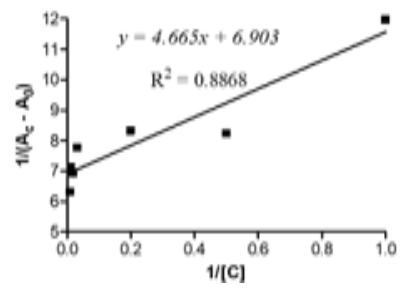

B

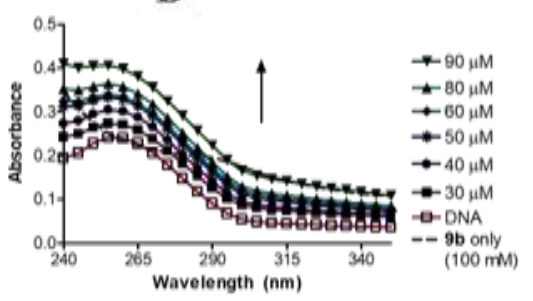

$\mathbf{E}$

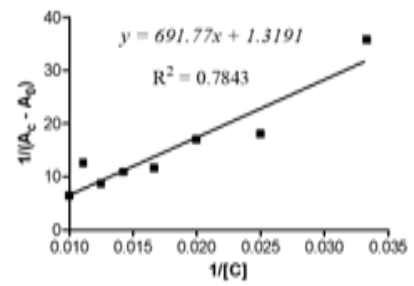

C

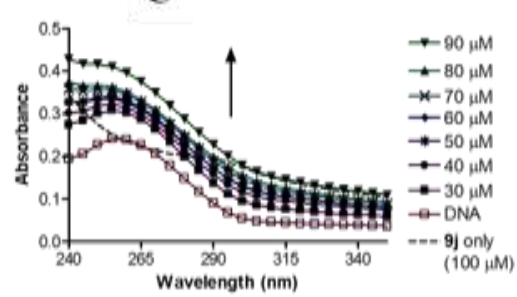

F

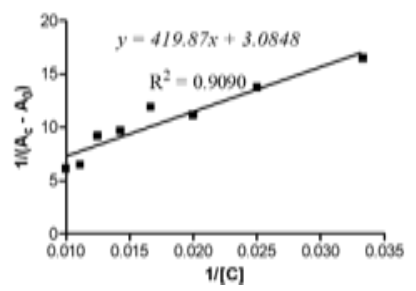

Figure 2 DNA binding results of compounds $9 \mathbf{a}, \mathbf{9 b}$ and $\mathbf{9 j}$. (A) $-(\mathbf{C})$ UV-Vis DNA titration spectra of $\alpha$-amino-o-cresols $9 \mathbf{a}(\mathbf{A}), 9 \mathbf{b}(\mathbf{B})$ and $\mathbf{9 j}(\mathbf{C})$ that produced a dose-dependent hyperchromic effect at $260 \mathrm{~nm}$ accompanied by a slight blue shift. (D) - (F) Guest-host reciprocal plots relating absorbance to compound concentration for $\alpha$-amino- $o$-cresols $9 \mathbf{a}(\mathbf{D})$, 9b (E) and 9j (F). 
The binding constant of each compound was determined as the ratio of the slope to $y$-intercept of the equation generated by linear regression. ${ }^{[29]}$ The binding constant for the 4-Me derivative 9b was $1.91 \times 10^{3} \mathrm{M}^{-1}$, and $1.48 \times 10^{6}$ and $7.35 \times 10^{3} \mathrm{M}^{-1}$ for the brominated analogues, $9 \mathbf{a}$ and 9j, respectively. These findings appeared to be in agreement with the in vitro evaluation data of the compounds as compound 9a with a superior binding constant exhibited both the highest antiplasmodial and antiproliferative potencies in the entire series (Tables 1 and 2). The discrepancies in the binding constants of $\mathbf{9 b}$ and $\mathbf{9 j}$ in relation to their in vitro antiplasmodial (3D7) and antiproliferative activity may be influenced by possible differences in their ability to penetrate the cells of the targeted diseases as a result of lipophobicity factors, among others. This is supported by the dissimilar $C \log \mathrm{P}$ values of these compounds as presented in Table 3, i.e. $9 \mathbf{b} C \log \mathrm{P}=4.24$ vs. 9j $C \log \mathrm{P}=4.97$. Notwithstanding, these results demonstrate that one of the possible modalities of the investigated compounds likely involves DNA interaction.

The mode by which an external ligand interacts with a DNA structure is determined by a number of factors such as its size, bonding within the molecule and its orientation in 3D space, i.e., topology, and conformation of the DNA structure. For instance, complex bulky molecules, like natural products azinomycins and pluramycins, tend to bind to the DNA major groove, whereas simple, flat (2D) ligands prefer minor groove binding. ${ }^{[44-45]}$ The UV-Vis DNA titration experiments of the ferrocenyl $\alpha$-amino- $o$-cresols above merely established that the compounds interact with DNA, possibly via external associations (Figure 2). Next in our investigations, we endeavoured to elucidate the mode of interaction by which the compounds bind to DNA using the strongest DNA binder from the UV-Vis titration experiment, i.e., compound 9a, as a tool compound. Employing previously described Hoechst (DNA minor groove binder) and methylene blue (DNA intercalator) competitive DNA binding assays, interrogation of the binding mode of compound 9a was undertaken. ${ }^{[23,46-47]}$ Hoechst 33342, a confirmed DNA minor groove binder, produces an intense fluorescence emission at $460-485 \mathrm{~nm}$ when bound 
to DNA. ${ }^{[48-49]}$ In the presence of a competing DNA minor groove binder, the DNA-bound Hoechst 33342 dye molecules will be competitively displaced from the DNA structure, leading to fluorescence attenuation. ${ }^{[49]}$ On the other hand, methylene blue, which is a strong DNA intercalator, emits strong fluorescence at $660-670 \mathrm{~nm}$ that gets diminished when the dye is bound to DNA.${ }^{[50]}$ Compounds that disrupt the DNA-methylene blue intercalation interactions, such as other intercalators, e.g., acridine, or cross-linkers, e.g., cisplatin, lead to an increase in the methylene blue fluorescence emission as more molecules of the dye are liberated from DNA. ${ }^{[23,51]}$ In our case, the fluorescence emission of the DNA-Hoechst 33342 complex (DNAHoechst) was reduced by $\sim 50 \%$ upon addition of compound 9a $(100 \mu \mathrm{M})$, indicating minor groove binding (Figure 3A). On the contrary, addition of 50 and $100 \mu \mathrm{M}$ of the test compound to the DNA-methylene blue adduct (DNA-MB) did not cause an increase in fluorescence, thus, dismissing 9a as a DNA intercalator (Figure 3B). The methylene blue DNA competitive binding assay was confirmed by adding a DNA cross-linker cisplatin as a positive control to the complex, which intensified the fluorescence of the sample indicating more dye molecules were being displaced from DNA (Figure 3C). 
A

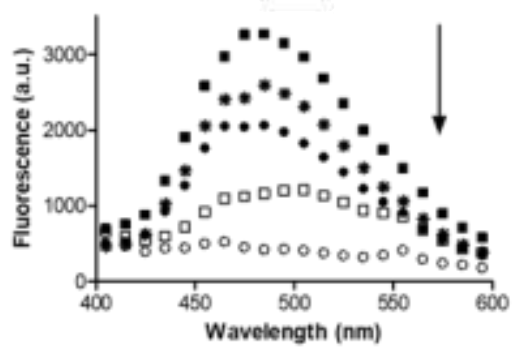

C

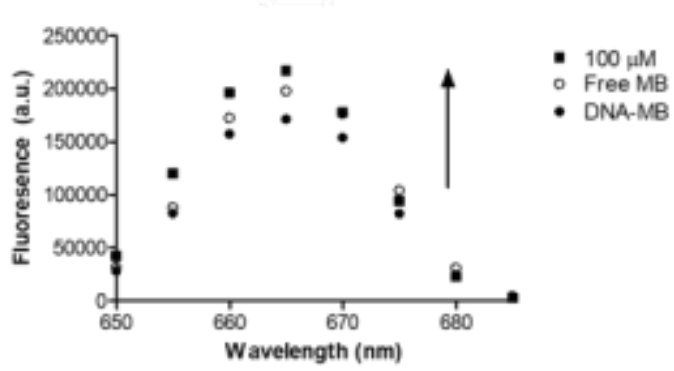

B

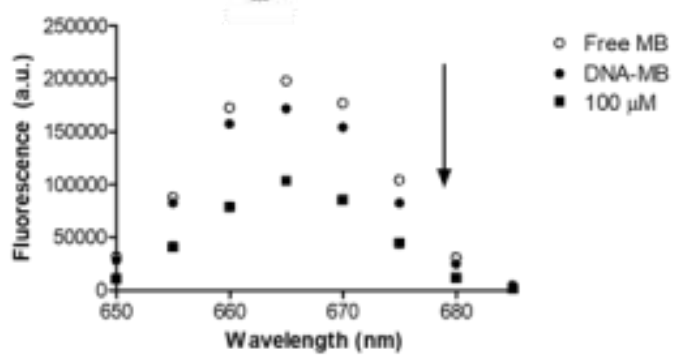

D

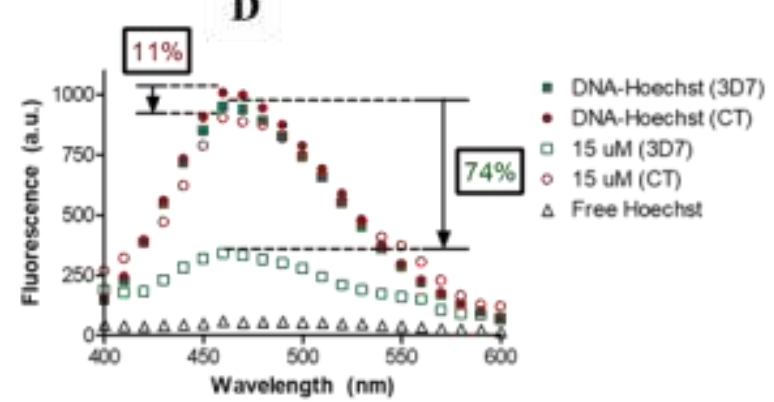

Figure 3 Results of the Hoechst 33342 and methylene blue competitive DNA binding assay for minor groove binding and intercalation. (A) Competitive Hoechst 33342 DNA binding results of compound 9a on calf thymus DNA. (B) Competitive methylene blue DNA binding results of compound 9a. (C) Competitive methylene blue DNA binding results of cisplatin. (D) Results of the Hoechst assay for selective binding of compound 9a between mammalian (CT) and malarial (3D7) DNA.

The compounds were generally more selective for the $P$. falciparum strains (3D7 and Dd2) over the mammalian HCC70 triple-negative breast cancer cell line. This preferential efficacy for the malaria parasite seemed justified due to the demonstrated hemozoin inhibitory activity of the compounds which provides complementary modality in addition do DNA interaction, thereby enhancing the antiplasmodial activity of the compounds. However, the genomic differences between mammalian and plasmodial DNA resulting in differences in the composition of the two DNA types, particularly the unusually high AT content of plasmodial DNA, could affect the binding sites for external compounds and provide further explanation 
for the marked selectivity of the compounds for the $P$. falciparum parasites over the mammalian HCC70 cancer cells. ${ }^{[52-53]}$ The Hoechst DNA binding assay already validated the compounds as DNA minor groove binders. Using the same assay, we qualitatively assessed the selective binding ability of compound 9a between the mammalian calf thymus DNA and DNA isolated from 3D7 P. falciparum strain. In the assay a $2.5 \mathrm{ng} / \mu \mathrm{L}$ DNA concentration of either mammalian calf thymus DNA (CT) or 3D7 P. falciparum DNA (3D7) and Hoechst 33342 (1.0 $\mu \mathrm{g} / \mathrm{mL})$ were incubated with a fixed concentration of $9 \mathbf{a}(15 \mu \mathrm{M})$ after which fluorescence was monitored as previously described. The results of the assay are illustrated in Figure 3D. The test compound induced a significant percentage fluorescence quenching of $74 \%$ on the 3D7 DNA-Hoechst complex vis-à-vis the calf thymus DNA, which showed $11 \%$ fluorescence quenching, decisively demonstrating the preferred binding selectivity of the compounds for the plasmodial DNA over the mammalian DNA. Thus, the enhanced plasmocidal efficacy of the investigated compounds compared to anticancer activity is further explained by their preferential binding to plasmodial DNA over mammalian DNA in addition to hemozoin inhibition.

Furthermore, the electrochemical character of the ferrocene unit is associated with the production of reactive oxygen species (ROS) in vitro and in vivo, ${ }^{[54]}$ which is essential for biological activity including the induction of DNA damage as documented in previous studies in literature. ${ }^{[55-58]}$ Thus, for future work it would be worthwhile to investigate the electrochemical behaviour of the investigated ferrocenyl compounds in order to provide insight into their ability to produce ROS as a possible complementary mechanistic pathway for their antiplasmodial and antiproliferative activity, in addition to hemozoin binding and DNA interaction. 


\section{Computational molecular docking simulations}

Computational molecular docking simulations were performed with AutoDock Vina using a computer-generated hemozoin crystal model and a B-DNA structure from protein data bank (PDB code: 1DSI) as biomolecular receptors and $(S)$-planar enantiomers of $9 \mathbf{a}, \mathbf{9 j}, \mathbf{1 2} \mathbf{a}$ and $\mathbf{1 4 a}$ as ligands to corroborate the $\beta$-hematin and DNA binding experimental data. The model of the hemozoin crystal was constructed as a super cell $(3 \times 3 \times 3$ unit cell $)$ in BIOVIA Materials Studio 2017 (Dassault Systèmes BIOVIA Materials Studio 2017 v17.1.0.48, San Diego: Dassault Systèmes, 2017) using a resolved X-ray crystal unit of hemozoin (CCDC code: XETXUP01) as a template and optimized according to the parameters reported by Egan and co-workers. ${ }^{[59-}$ ${ }^{60]}$ On the other hand, the DNA receptor (PDB code: 1SDI) was prepared in BIOVIA Discovery Studio Client 2019 (Dassault Systèmes BIOVIA Discovery Studio Client 2019 v19.0.18287, San Diego: Dassault Systèmes, 2019). The binding simulations were run using the AutoDock Vina software package and the results analysed in BIOVIA Discovery Studio Client 2019. ${ }^{[31]}$

The binding interactions of the compounds with the hemozoin receptor were primarily by noncovalent bonding associations such as van der Waals forces and $\pi-\pi$ interactions. In all instances, the compounds bound to the corrugated (001) face and the (010) side face of the hemozoin crystal. ${ }^{[37]}$ The benzene ring of the predicted most stable conformers of the ligands bound to the grooves created between the repeating, stacking hemozoin units on the fastgrowing (001) face of the crystal, forming multiple $\pi$ - $\pi$ contacts with the protruding, parallel pyrrole rings of the porphyrin subunits (aromatic $\pi-\pi$ interactions, $4.30-4.75 \AA$ ), while the steric bulk and 3D geometry of the ferrocene unit projected this moiety towards the dents between adjacent hemozoin units (Figure 4A-B). Aromatic $\pi-\pi$ associations were also observed for the latter binding interactions between the ferrocenyl cyclopentadiene rings and the porphyrinoid pyrrole units of the crystal for $(S)-9 \mathbf{a}$ (aromatic $\pi-\pi$ interactions, 3.834 and 4.472 $\AA$ ), adding further stabilisation to the complex (Figure 4A). Interestingly, the presence 
of the 4-Br substituent was favourable for the binding of brominated analogues $(S)-\mathbf{9 a}$ and $\mathbf{9 j}$ as shown by the formation of halogen-assisted non-covalent interactions with the porphyrinoid methyl $\left(\mathrm{CH}_{3}\right)$ and electron rich methylene $\left(\mathrm{HC}=\mathrm{CH}_{2}\right)$ units of the hemozoin crystal $(3.898-$ $3.917 \AA$ ) (Figure 4A-B). The docked structures of the non-brominated analogues 12a and 14a lacked these stabilizing interactions in their simulated poses, and their biological activity was inferior to that of $\mathbf{9 a}$ and $\mathbf{9 j}$ containing the 4-Br substituent (Figure S4A-B). The beneficial binding effects of the 4-Br substituent in the docking simulations are in agreement with the SAR trends noted for the antiplasmodial and antiproliferative biological data of the investigated compounds.

For the simulated poses that interacted with the (010) side face of the hemozoin crystal, aminocresol (S)-9a formed a pi-anion interaction (4.609 $\AA$ ) between the benzene unit and the porphyrin nitrogen atom from hemozoin and a non-classical hydrogen bond $\left(\mathrm{C}=\mathrm{O} \cdots \mathrm{CH}_{3}-\right.$ $\mathrm{NCH}_{3}, 3.678 \AA$ ) via the ferrocenyl $\mathrm{CH}_{2} \mathrm{NMe}_{2}$ moiety with the receptor, underscoring the significance of this motif (Figure S4C-D). A classical hydrogen bond was formed between the phenolic oxygen of $(S)-\mathbf{9} \mathbf{j}$ and the hemozoin propionic $\mathrm{OH}$ group $(\mathrm{HO} \cdots \mathrm{HO}-\mathrm{CO}, 3.138 \AA$ ), adding further stabilization to the adduct. These additional interactions were absent in the nonphenolic benzylamine $(S)$-12a and the rotationally limited salicylamide $(S)$-14a (Figure S4EF). These observations indicate the pharmacological role of these structural features, i.e., phenolic $\mathrm{OH}$ and rotatable $\mathrm{C}-\mathrm{NH}$ bond, on the biological activity of investigated compounds as previously stated. There was no direct correlation between the observed antimalarial activity of the compounds and the predicted binding energies. However, though comparable, the predicted binding energies of most active forms of the compounds to the hemozoin crystal were below $-5 \mathrm{kcal} / \mathrm{mol}$ for all the compounds, indicative of stable interactions (Table 4). ${ }^{[61]}$ These data seemed to corroborate the findings of the $\beta$-hematin binding assay. 

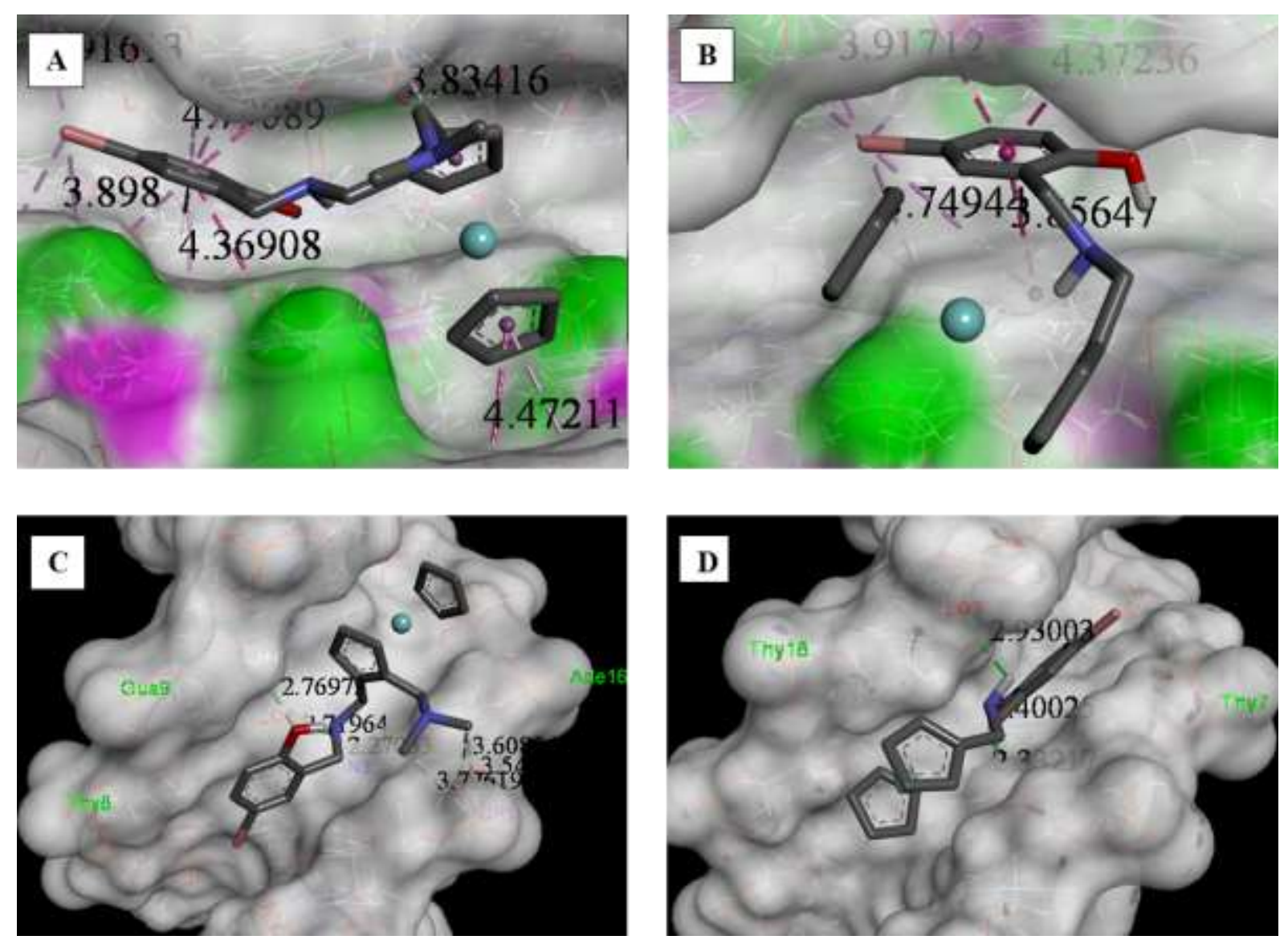

Figure 4 Molecular docking simulation results of aminocresols $\mathbf{9 a}$ and $\mathbf{9 j}$. Predicated active poses of compound 9a (A) and $9 \mathbf{j}(\mathbf{B})$ bound to the corrugated (001) face of the hemozoin crystal. Structures of simulated active conformers of compound 9a $(\mathbf{C})$ and $9 \mathbf{j}(\mathbf{D})$ interacting with the DNA minor groove. The labels in black indicate the distance of the binding interactions in angstroms $(\AA)$ between the compounds and receptors, and the green annotations represent the DNA bases interacting with the compounds.

For the DNA binding simulations, all the predicted conformations of compounds $9 \mathbf{a}, 9 \mathbf{j}, \mathbf{1 2} \mathbf{a}$ and 14a exclusively bound to the minor groove of the B-DNA receptor structure, as experimentally determined by the competitive Hoechst 33342 DNA binding assay (Video 1). The DNA-compound complexes were mainly stabilized by both classical and non-classical hydrogen bonding between the predicted active conformers of the compounds and the DNA receptor. Classical hydrogen bonding $(2.20-3.20 \AA)$ with the DNA bases was exhibited by all 
the simulated poses of the compounds via either the phenolic $\mathrm{OH}$ or aliphatic $\mathrm{NH}$ group, whilst non-classical interactions $(3.5-4.0 \AA)$ were between the phosphate units of the DNA backbone and the Me groups of the ferrocenyl $\mathrm{CH}_{2} \mathrm{NMe}_{2}$ motif as exemplified by the simulated DNAbound structures of aminocresols 9a and 9j (Figure 4C-D). Similar to the hemozoin binding simulation results, the bulky ferrocene unit formed a best fit for the DNA minor groove owing to its 3D shape with the flat benzene ring aligned along the same axis, and the predicted binding energies were all symbolic of stable ligand-receptor interactions $(<-5.0 \mathrm{kcal} / \mathrm{mol})$. The simulated binding energies of the compounds seemed to correlate with their observed in vitro biological activity. For instance, compound 12a lacking the hydrogen-bond donating phenolic $\mathrm{OH}$ group exhibited inferior binding energy and biological activity compared to the aminocresols 9a and 9j endowed with this group (Table 4). Additionally, the more favourable binding energy of $9 \mathbf{a}(-8.6 \mathrm{kcal} / \mathrm{mol})$ relative to $9 \mathbf{j}(-7.3 \mathrm{kcal} / \mathrm{mol})$ was in agreement with both the toxicity of the compounds and their DNA binding constants from UV/Vis titration experiments. These observations appeared to support DNA interaction as a possible mode of action of the investigated compounds.

Table 4 Predicted binding energies of compounds $9 \mathbf{a}, \mathbf{9 j}, \mathbf{1 2 a}$ and $\mathbf{1 4 a}$ from the hemozoin and DNA binding simulations.

\begin{tabular}{|ccccc|}
\hline \multirow{2}{*}{ Compound } & \multicolumn{2}{c}{ Binding energy $(\mathbf{k c a l} / \mathbf{m o l})$} & \multicolumn{2}{c|}{ IC50 $(\boldsymbol{\mu M})$} \\
\cline { 2 - 5 } & Hemozoin & DNA & 3D7 & HCC70 \\
\hline $\mathbf{9 a}$ & -7.9 & -8.1 & $1.6 \pm 0.04$ & 6.67 \\
$\mathbf{9 j}$ & -8.4 & -7.3 & $2.3 \pm 0.28$ & na \\
$\mathbf{1 2 a}$ & -7.5 & -6.7 & $2.99 \pm 0.30$ & na \\
$\mathbf{1 4 a}$ & -8.4 & -7.2 & $9.64 \pm 1.17$ & na \\
\hline
\end{tabular}


In summary, the experimental mechanistic studies were validated using computer-aided molecular docking simulations. The simulated binding interactions between the compounds and the investigated targets, i.e., hemozoin and DNA, provide insight into the role played by the structural features of the compounds, thus confirming the elucidated SAR trends. These findings, together with the experimental mechanistic studies, strongly suggest that the possible mode of action of the $\alpha$-amino- $o$-cresols pursued in this paper likely involves a combination of hemozoin inhibition and DNA interaction. Additionally, the hemozoin inhibition results and the preferential binding of these compounds to the plasmodial DNA over mammalian DNA are encouraging for further exploration of the presented ferrocenyl chemotypes as dual modal antiplasmodial agents.

\section{CONCLUSION}

Herein, we presented the antiplasmodial and anticancer activity of new, structurally simple organometallic compounds assembled by incorporation of the ferrocene unit into the antimalarial $\alpha$-amino- $o$-cresol scaffold. The compounds showed higher selectivity for the malarial 3D7 and Dd2 strains of the $P$. falciparum parasite, with no indication of crossresistance, than the human HCC70 breast cancer cells. Comprehensive SAR elucidation of the ferrocenyl $\alpha$-amino-o-cresol structural architecture accomplished by synthesizing rotatable benzylamine and rotationally constrained salicylamide variants revealed that the phenolic $\mathrm{OH}$ group and the rotatable $\mathrm{C}-\mathrm{NH}$ bond are vital for biological activity, possibly due to formation of an intramolecular hydrogen bond. The spectrophotometric DNA titration experiments and $\beta$-hematin binding assay, which were supported by in silico docking simulations, strongly suggest DNA interaction involving minor groove binding and hemozoin inhibition as plausible mechanistic modalities via which the compounds exert biological activity, thus presenting them as potential antimalarial agents with a dual mode of action. Preferential binding affinity of tool compound 9a for the plasmodial DNA over the mammalian DNA, together with hemozoin 
inhibitory affinity, substantiate the higher selectivity of the compounds for the $P$. falciparum strains. The findings of the current study demonstrate the concept of introducing organometallic complexes into bioactive organic scaffolds as a viable approach to devise novel therapeutic agents with potential to evade or delay the development of clinical resistance by targeting multiple mechanistic pathways. These results support further investigation and development of the studied ferrocenyl aminocresols as antimalarial and anticancer agents. 


\section{EXPERIMENTAL}

\section{Materials and instrumentation}

All the chemicals used in the study were sourced from Merck (South Africa) and used without further purification. The calf thymus DNA was purchased from Thermo Fischer Scientific (South Africa). The 3D7 P. falciparum DNA was isolated from cultured 3D7 trophozoites according to the manufacturer's instructions using the Quick-DNA Miniprep Kit (\#D3024/D3025) (Zymo Research, Irvine, CA, USA). The progress of each reaction was monitored by thin-layer chromatography on Merck $\mathrm{F}_{254}$ silica gel plates and product visualized under ultraviolet light (UV 254 and $366 \mathrm{~nm}$ ). The melting points of the compounds were determined using the Stuart SMP30 melting point apparatus and were uncorrected. The NMR spectra of the compounds were recorded on Bruker Biospin 400 and $600 \mathrm{MHz}$ NMR spectrometers and the residual signals of chloroform- $d$ (7.26 ppm for ${ }^{1} \mathrm{HNMR}$ and $77.16 \mathrm{ppm}$ for $\left.{ }^{13} \mathrm{CNMR}\right)$ and DMSO- $d_{6}\left(2.50 \mathrm{ppm}\right.$ for ${ }^{1} \mathrm{HNMR}$ and $39.52 \mathrm{ppm}$ for $\left.{ }^{13} \mathrm{CNMR}\right)$ were used as internal references. Assignment of proton signals was achieved by multiplet analysis as well as 2D NMR techniques: COSY and HSQC NMR (Supporting Information). The HPLC purity of the compounds was determined on an Agilent 1100 Series HPLC instrument

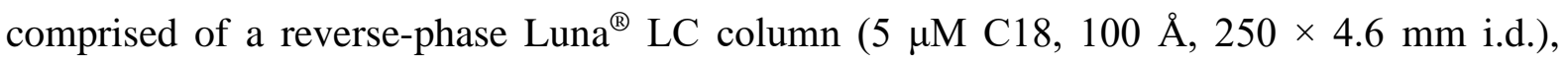
G1315B diode-array detector (DAD), G1311A quaternary pump, G1322A degasser and a G1328B manual injector, and the compounds were run by isocratic elution in $5 \% \mathrm{NH}_{4} \mathrm{Cl}(\mathrm{w} / \mathrm{v})$ buffer ( $\mathrm{pH} 8.0)$ in acetonitrile for a total running time of 8 minutes. The high-resolution mass spectrometry (HRMS) data were acquired on Waters Synapt G2 Mass Spectrometer (Central Analytical Facility, University of Stellenbosch) using the electrospray ionization (ESI) method set to positive ionization mode. The UV-Vis and fluorescent spectra for DNA binding assays were recorded on a SpectraMax M3 microplate reader (Molecular Devices, San Jose, CA, USA). 


\section{General procedure for synthesis of ferrocenyl $\alpha$-amino-o-cresols (9a-m) and benzylamines $(12 \mathbf{a}-\mathbf{b})^{[26]}$}

To a solution of ferrocenyl amine 7a-b (1.0. eq.) in EtOH (5 mL) was added an appropriate salicyaldehyde 10a-i or aldehyde 11a-c (1.0 eq.) and the resulting suspension was refluxed for 4 hours. Upon completion, the reaction mixture was allowed to cool to room temperature followed by addition of sodium borohydride ( 2.0 eq.). The reaction mixture was stirred at room temperature for 15 minutes and then refluxed for another 15 minutes. Following cooling to room temperature, $2 \mathrm{~N} \mathrm{HCl}$ solution $(2 \times 25 \mathrm{~mL})$ was added to extract the product into the aqueous phase and washed with EtOAc $(2 \times 15 \mathrm{~mL})$. The aqueous layer was basified with $1 \mathrm{~N}$ $\mathrm{NaOH}$ solution $(\mathrm{pH} 8)$ and the product extracted with $\mathrm{DCM}(2 \times 25 \mathrm{~mL})$. The collected organic layers were combined, dried $\left(\mathrm{Na}_{2} \mathrm{SO}_{4}\right)$ and the solvent was removed under reduced pressure to afford the title compound in high purity. In some cases, the product was purified by column chromatography on basic alumina using gradient elution $(\mathrm{DCM} \rightarrow 1: 9 \mathrm{MeOH} / \mathrm{DCM})$ to furnish the pure compound.

\section{$N$-2-((N,N-Dimethylamino)methyl)ferrocenemethyl 4-bromo- $\alpha$-amino-o-cresol (9a)}

Brown viscous oil. Yield: $138.0 \mathrm{mg}(41 \%) .{ }^{1} \mathrm{H} \mathrm{NMR}\left(600 \mathrm{MHz}, \mathrm{CDCl}_{3}\right) \delta 7.24(\mathrm{~d}, J=7.6 \mathrm{~Hz}$, 1H, $\left.\mathrm{H}_{5}\right), 7.05$ (br s, 1H, H3), $6.72\left(\mathrm{~d}, J=8.5 \mathrm{~Hz}, 1 \mathrm{H}, \mathrm{H}_{6}\right), 4.12(\mathrm{~s}, 2 \mathrm{H}, \mathrm{FcH}), 4.07-4.06$ (m, 1H, FcH), $4.03(\mathrm{~s}, 5 \mathrm{H}, \mathrm{FcH}), 3.84-3.79\left(\mathrm{~m}, 3 \mathrm{H}, \mathrm{H}_{2^{\prime} \mathrm{a}}, \mathrm{H}_{2}{ }^{\prime}\right), 3.75$ (d, J = 12.6 Hz, 1H, H $\left.\mathrm{H}^{\prime} \mathrm{a}\right), 3.31$ (d, $\left.J=13.5 \mathrm{~Hz}, 1 \mathrm{H}, \mathrm{H}_{2} \mathrm{~b}\right), 2.77\left(\mathrm{~d}, J=12.6 \mathrm{~Hz}, 1 \mathrm{H}, \mathrm{H}_{1} \mathrm{~b}^{\mathrm{b}}\right), 2.13\left(\mathrm{~s}, 6 \mathrm{H}, \mathrm{NMe}_{2}\right) ;{ }^{13} \mathrm{C} \mathrm{NMR}(150$ $\left.\mathrm{MHz}, \mathrm{CDCl}_{3}\right) \delta 158.3,131.3,131.1,124.5,118.3,110.4,84.1,83.9,71.5,70.8,69.2(5 \mathrm{C}), 66.1$, 58.4, 50.2, 45.9, 44.9 (2C); HRMS $\left(\mathrm{ESI}^{+}\right) \mathrm{m} / z$ calcd for $\mathrm{C}_{21} \mathrm{H}_{25} \mathrm{BrFeN}_{2} \mathrm{O}$ : 456.0500, Found $457.0573[\mathrm{M}+\mathrm{H}]^{+} ;$HPLC purity $>82 \%\left(t_{\mathrm{R}}=3.06 \mathrm{~min}\right)$. 
Brown semi-solid. Yield: $86.5 \mathrm{mg}(63 \%) .{ }^{1} \mathrm{H} \mathrm{NMR}\left(600 \mathrm{MHz}, \mathrm{CDCl}_{3}\right) \delta 6.97(\mathrm{dd}, J=8.1,1.6$ $\left.\mathrm{Hz}, 1 \mathrm{H}, \mathrm{H}_{5}\right), 6.76\left(\right.$ br s, $\left.1 \mathrm{H}, \mathrm{H}_{3}\right), 6.74\left(\mathrm{~d}, J=8.1 \mathrm{~Hz}, 1 \mathrm{H}, \mathrm{H}_{6}\right), 4.14-4.10(\mathrm{~m}, 2 \mathrm{H}, \mathrm{FcH}), 4.05$ $(\mathrm{t}, J=2.4 \mathrm{~Hz}, 1 \mathrm{H}, \mathrm{FcH}), 4.02(\mathrm{~s}, 5 \mathrm{H}, \mathrm{FcH}), 3.82\left(\mathrm{~d}, J=6.0 \mathrm{~Hz}, 2 \mathrm{H}, \mathrm{H}_{2^{\prime \prime}}\right), 3.78(\mathrm{~d}, J=13.5 \mathrm{~Hz}$, $\left.1 \mathrm{H}, \mathrm{H}_{1^{\prime} \mathrm{a}}\right), 3.72\left(\mathrm{~d}, J=12.6 \mathrm{~Hz}, 1 \mathrm{H}, \mathrm{H}_{2^{\prime} \mathrm{a}}\right), 3.34\left(\mathrm{~d}, J=13.5 \mathrm{~Hz}, 1 \mathrm{H}, \mathrm{H}_{2^{\prime} \mathrm{b}}\right), 2.76(\mathrm{~d}, J=12.6 \mathrm{~Hz}$, $\left.1 \mathrm{H}, \mathrm{H}_{1^{\prime} \mathrm{b}}\right), 2.25$ (s, 3H, Me), $2.12\left(\mathrm{~s}, 6 \mathrm{H}, \mathrm{NMe}_{2}\right) ;{ }^{13} \mathrm{C} \mathrm{NMR}\left(150 \mathrm{MHz}, \mathrm{CDCl}_{3}\right) \delta 152.7,131.4$, $129.1,128.0,126.1,115.0,85.2,71.1,70.3,69.0$ (5C), 66.1, 58.0, 52.6, 47.2, 45.8, 43.9 (2C); 20.3; HRMS $\left(\mathrm{ESI}^{+}\right) \mathrm{m} / \mathrm{z}$ calcd for $\mathrm{C}_{22} \mathrm{H}_{28} \mathrm{FeN}_{2} \mathrm{O}$ : 392.1551 , Found $393.1632[\mathrm{M}+\mathrm{H}]^{+}$; HPLC purity $>99 \%\left(t_{\mathrm{R}}=3.04 \mathrm{~min}\right)$.

\section{$N$-2-((N,N-Dimethylamino)methyl)ferrocenemethyl 4-nitro- $\alpha$-amino-o-cresol (9c)}

Yellow semi-solid. Yield: $98.8 \mathrm{mg}(55 \%) .{ }^{1} \mathrm{H}$ NMR (600 MHz, $\left.\mathrm{CDCl}_{3}\right) \delta 8.10-8.05(\mathrm{~m}, 1 \mathrm{H}$, $\left.\mathrm{H}_{5}\right), 7.87\left(\mathrm{~d}, J=2.8 \mathrm{~Hz}, 1 \mathrm{H}, \mathrm{H}_{3}\right), 6.71\left(\mathrm{~d}, J=9.0 \mathrm{~Hz}, 1 \mathrm{H}, \mathrm{H}_{6}\right), 4.16$ (br s, $\left.1 \mathrm{H}, \mathrm{FcH}\right), 4.15$ (br s, 1H, FcH), $4.11(\mathrm{~s}, 1 \mathrm{H}, \mathrm{FcH}), 4.06-4.02\left(\mathrm{~m}, 7 \mathrm{H}, \mathrm{FcH}, \mathrm{H}_{2 "}\right), 3.89$ (d, J = 13.6 Hz, 1H, H $\left.{ }^{\prime} \mathrm{a}\right)$, $3.79\left(\mathrm{~d}, J=13.6 \mathrm{~Hz}, 1 \mathrm{H}, \mathrm{H}_{2^{\prime} \mathrm{b}}\right), 3.39$ (d, $\left.J=12.7 \mathrm{~Hz}, 1 \mathrm{H}, \mathrm{H}_{1^{\prime}} \mathrm{a}\right), 2.79$ (d, $\left.J=12.7 \mathrm{~Hz}, 1 \mathrm{H}, \mathrm{H}_{1^{\prime} \mathrm{b}}\right)$, $2.13\left(\mathrm{~s}, 6 \mathrm{H}, \mathrm{NMe}_{2}\right) ;{ }^{13} \mathrm{C} \mathrm{NMR}\left(150 \mathrm{MHz}, \mathrm{CDCl}_{3}\right) \delta 136.2,128.3,126.0,125.1,121.9,116.8$ 83.9 (2C), 71.7, 71.0, 69.2, 69.2 (5C), 66.4, 58.2, 44.7, 44.6 (2C); HRMS (ESI $\left.{ }^{+}\right) \mathrm{m} / \mathrm{z}$ calcd for $\mathrm{C}_{21} \mathrm{H}_{25} \mathrm{FeN}_{3} \mathrm{O}_{3}: 423.1245$, Found $423.1986[\mathrm{M}+\mathrm{H}]^{+}$; HPLC purity $>93 \%\left(t_{\mathrm{R}}=4.83 \mathrm{~min}\right)$.

\section{$N$-2-((N,N-Dimethylamino)methyl)ferrocenemethyl $\alpha$-amino-o-cresol (9d)}

Brown semi-solid. Yield: $175.0 \mathrm{mg}(95 \%) .{ }^{1} \mathrm{H} \mathrm{NMR}\left(600 \mathrm{MHz}, \mathrm{CDCl}_{3}\right) \delta 7.17(\mathrm{t}, J=7.7 \mathrm{~Hz}$, $\left.1 \mathrm{H}, \mathrm{H}_{5}\right), 6.94\left(\mathrm{~d}, J=7.2 \mathrm{~Hz}, 1 \mathrm{H}, \mathrm{H}_{6}\right), 6.84\left(\mathrm{~d}, J=8.0 \mathrm{~Hz}, 1 \mathrm{H}, \mathrm{H}_{3}\right), 6.77\left(\mathrm{t}, J=7.4 \mathrm{~Hz}, 1 \mathrm{H}, \mathrm{H}_{4}\right)$, $4.11\left(\mathrm{~d}, J=2.5 \mathrm{~Hz}, 2 \mathrm{H}, \mathrm{H}_{2^{\prime \prime}}\right), 4.05(\mathrm{t}, J=2.5 \mathrm{~Hz}, 1 \mathrm{H}, \mathrm{FcH}), 4.02(\mathrm{~s}, 5 \mathrm{H}, \mathrm{FcH}), 3.86(\mathrm{~d}, J=7.9$ $\mathrm{Hz}, 2 \mathrm{H}, \mathrm{FcH}), 3.79$ (d, $\left.J=13.5 \mathrm{~Hz}, 1 \mathrm{H}, \mathrm{H}_{1^{\prime} \mathrm{a}}\right), 3.73\left(\mathrm{~d}, J=12.6 \mathrm{~Hz}, 1 \mathrm{H}, \mathrm{H}_{2^{\prime} \mathrm{a}}\right), 3.34(\mathrm{~d}, J=13.5$ $\left.\mathrm{Hz}, 1 \mathrm{H}, \mathrm{H}_{1^{\prime} \mathrm{b}}\right), 2.77\left(\mathrm{~d}, J=12.6 \mathrm{~Hz}, 1 \mathrm{H}, \mathrm{H}_{2^{\prime}} \mathrm{b}\right), 2.12\left(\mathrm{~s}, 6 \mathrm{H}, \mathrm{NMe}_{2}\right) ;{ }^{13} \mathrm{C} \mathrm{NMR}\left(150 \mathrm{MHz}, \mathrm{CDCl}_{3}\right)$ $\delta 159.1,128.5$ (2C), 122.6, 118.8, 116.4, 84.6, 84.1, 71.3, 70.7, 69.1 (5C), 66.0, 58.4, 50.8, 
45.9, 45.0 (2C); HRMS (ESI $\left.{ }^{+}\right) \mathrm{m} / z$ calcd for $\mathrm{C}_{21} \mathrm{H}_{26} \mathrm{FeN}_{2} \mathrm{O}$ : 378.1395, Found 379.1467

$[\mathrm{M}+\mathrm{H}]^{+} ;$HPLC purity $>99 \%\left(t_{\mathrm{R}}=2.97 \mathrm{~min}\right)$.

\section{$N$-2-((N,N-Dimethylamino)methyl)ferrocenemethyl 6-methoxy- $\alpha$-amino-o-cresol $(9 \mathrm{e})$}

Light brown viscous oil. Yield: $228.8 \mathrm{mg}(76 \%) .{ }^{1} \mathrm{H}$ NMR $\left(600 \mathrm{MHz}, \mathrm{CDCl}_{3}\right) \delta 6.82(\mathrm{~d}, J=$ $\left.7.9 \mathrm{~Hz}, 1 \mathrm{H}, \mathrm{H}_{5}\right), 6.75$ (t, $\left.J=7.8 \mathrm{~Hz}, 1 \mathrm{H}, \mathrm{H}_{4}\right), 6.67$ (d, J = 7.5 Hz, 1H, H3), 4.17 (br s, 1H, FcH), 4.13 (br s, 1H, FcH), 4.06 (t, $J=2.4 \mathrm{~Hz}, 1 \mathrm{H}, \mathrm{FcH}), 4.03(\mathrm{~s}, 5 \mathrm{H}, \mathrm{FcH}), 3.93(\mathrm{~d}, J=6.0 \mathrm{~Hz}, 1 \mathrm{H}$, $\mathrm{H}_{2 " \mathrm{a}}$ ), 3.91 (d, $J=6.0 \mathrm{~Hz}, 1 \mathrm{H}, \mathrm{H}_{2 " \mathrm{~b}}$ ), 3.88 (s, 3H, OMe), 3.85 (d, $\left.J=14.0 \mathrm{~Hz}, 1 \mathrm{H}, \mathrm{H}_{2}^{\prime} \mathrm{a}\right), 3.77$ (d, $\left.J=12.7 \mathrm{~Hz}, 1 \mathrm{H}, \mathrm{H}_{1^{\prime} \mathrm{a}}\right), 3.43\left(\mathrm{~d}, J=14.0 \mathrm{~Hz}, 1 \mathrm{H}, \mathrm{H}_{2^{\prime} \mathrm{b}}\right), 2.81\left(\mathrm{~d}, J=12.7 \mathrm{~Hz}, 1 \mathrm{H}, \mathrm{H}_{1^{\prime} \mathrm{b}}\right), 2.12(\mathrm{~s}$, $\left.6 \mathrm{H}, \mathrm{NMe}_{2}\right) ;{ }^{13} \mathrm{C} \mathrm{NMR}\left(150 \mathrm{MHz}, \mathrm{CDCl}_{3}\right) \delta 148.0,147.8,122.1,120.9,118.5,110.8,83.8$, 83.6, 71.4, 71.0, 69.1 (5C), 66.1, 58.2, 56.0, 49.6, 45.7, 44.8 (2C); HRMS (ESI ${ }^{+}$) $\mathrm{m} / z$ calcd for $\mathrm{C}_{22} \mathrm{H}_{28} \mathrm{FeN}_{2} \mathrm{O}_{2}: 408.1500$, Found $409.1581[\mathrm{M}+\mathrm{H}]^{+} ;$HPLC purity $>82 \%\left(t_{\mathrm{R}}=3.23 \mathrm{~min}\right)$.

\section{$N$-2-((N,N-Dimethylamino)methyl)ferrocenemethyl 6-nitro- $\alpha$-amino-o-cresol (9f)}

Light yellow sticky solid. Yield: $48.2 \mathrm{mg}(38 \%) .{ }^{1} \mathrm{H}$ NMR $\left(600 \mathrm{MHz}, \mathrm{CDCl}_{3}\right) \delta 7.90(\mathrm{~d}, J=$ $\left.8.2 \mathrm{~Hz}, 1 \mathrm{H}, \mathrm{H}_{5}\right), 7.06\left(\mathrm{~d}, J=6.6 \mathrm{~Hz}, 1 \mathrm{H}, \mathrm{H}_{3}\right), 6.32\left(\mathrm{t}, J=7.6 \mathrm{~Hz}, 1 \mathrm{H}, \mathrm{H}_{4}\right), 4.48(\mathrm{~d}, J=13.1 \mathrm{~Hz}$, 1H, $\left.\mathrm{H}_{2 ' \mathrm{a}}\right), 4.27(\mathrm{~s}, 1 \mathrm{H}, \mathrm{FcH}), 4.19(\mathrm{~d}, J=9.2 \mathrm{~Hz}, 1 \mathrm{H}, \mathrm{FcH}), 4.16(\mathrm{~s}, 1 \mathrm{H}, \mathrm{FcH}), 4.12(\mathrm{~s}, 5 \mathrm{H}$, $\mathrm{FcH}), 4.10-4.06\left(\mathrm{~m}, 1 \mathrm{H}, \mathrm{H}_{2^{\prime} \mathrm{b}}\right), 3.85-3.75\left(\mathrm{~m}, 2 \mathrm{H}, \mathrm{H}_{2^{\prime \prime}}\right), 3.65\left(\mathrm{~d}, J=12.9 \mathrm{~Hz}, 1 \mathrm{H}, \mathrm{H}_{1^{\prime} \mathrm{a}}\right), 3.37$ $\left(\mathrm{d}, J=6.7 \mathrm{~Hz}, 1 \mathrm{H}, \operatorname{exch~} \mathrm{D}_{2} \mathrm{O}, \mathrm{NH}\right), 2.88\left(\mathrm{~d}, J=12.8 \mathrm{~Hz}, 1 \mathrm{H}, \mathrm{H}_{1^{\prime} \mathrm{b}}\right), 2.17\left(\mathrm{~s}, 6 \mathrm{H}, \mathrm{NMe}_{2}\right) ;{ }^{13} \mathrm{C}$ NMR $\left(150 \mathrm{MHz}, \mathrm{CDCl}_{3}\right) \delta 135.3,127.3,126.6,125.8,122.9,111.6,83.7,77.4,71.9,71.8$, 69.7 (5C), 67.1, 57.7, 47.5, 45.4, 44.3 (2C); HRMS (ESI $\left.{ }^{+}\right) \mathrm{m} / z$ calcd for $\mathrm{C}_{21} \mathrm{H}_{25} \mathrm{FeN}_{3} \mathrm{O}_{3}$ : 423.1245, Found $424.1317[\mathrm{M}+\mathrm{H}]^{+}$; HPLC purity $>94 \%\left(t_{\mathrm{R}}=4.43 \mathrm{~min}\right)$.

\section{$N$-2-((N,N-Dimethylamino)methyl)ferrocenemethyl 4,6-dibromo-a-amino-o-cresol (9g)}

Red sticky solid. Yield: $170.1 \mathrm{mg}(83 \%) .{ }^{1} \mathrm{H}$ NMR (600 MHz, $\left.\mathrm{CDCl}_{3}\right) \delta 7.50\left(\mathrm{~s}, 1 \mathrm{H}, \mathrm{H}_{5}\right), 6.96$ (s, 1H, H5), $34.16(\mathrm{~s}, 2 \mathrm{H}, \mathrm{FcH}) 4.10(\mathrm{~s}, 1 \mathrm{H}, \mathrm{FcH}), 4.05$ (s, 5H, FcH), $3.98-3.91\left(\mathrm{~m}, 2 \mathrm{H}, \mathrm{H}_{2}{ }^{\prime \prime}\right)$, $3.82-3.77\left(\mathrm{~m}, 2 \mathrm{H}, \mathrm{H}_{2^{\prime} \mathrm{a}}, \mathrm{H}_{1^{\prime} \mathrm{a}}\right), 3.37$ (d, $\left.J=13.0 \mathrm{~Hz}, 1 \mathrm{H}, \mathrm{H}_{2^{\prime} \mathrm{b}}\right), 2.85\left(\mathrm{~d}, J=12.3 \mathrm{~Hz}, 1 \mathrm{H}, \mathrm{H}_{1^{\prime} \mathrm{b}}\right)$, 
$2.18\left(\mathrm{~s}, 6 \mathrm{H}, \mathrm{NMe}_{2}\right) ;{ }^{13} \mathrm{C} \mathrm{NMR}\left(150 \mathrm{MHz}, \mathrm{CDCl}_{3}\right) \delta 156.3,133.9,130.3,124.3,112.0,109.0$, 83.0, 82.7, 71.7, 71.2, 69.3 (5C), 66.7, 58.1, 49.7, 45.6, 44.6 (2C); HRMS (ESI $\left.{ }^{+}\right) \mathrm{m} / z$ calcd for $\mathrm{C}_{21} \mathrm{H}_{24} \mathrm{Br}_{2} \mathrm{FeN}_{2} \mathrm{O}$ : 533.9605, Found $534.9680[\mathrm{M}+\mathrm{H}]^{+}$; HPLC purity $>92 \%\left(t_{\mathrm{R}}=7.18 \mathrm{~min}\right)$.

\section{$N$-2-((N,N-Dimethylamino)methyl)ferrocenemethyl 6-bromo-4-nitro- $\alpha$-amino-o-cresol}

(9h)

Light orange semi-solid. Yield: $58.6 \mathrm{mg}(23 \%) .{ }^{1} \mathrm{H}$ NMR $\left(600 \mathrm{MHz}, \mathrm{CDCl}_{3}\right) \delta 8.46(\mathrm{~d}, J=2.8$ $\left.\mathrm{Hz}, 1 \mathrm{H}, \mathrm{H}_{5}\right), 7.82\left(\mathrm{~d}, J=2.8 \mathrm{~Hz}, 1 \mathrm{H}, \mathrm{H}_{3}\right), 4.32\left(\mathrm{~d}, J=13.6 \mathrm{~Hz}, 1 \mathrm{H}, \mathrm{H}_{2} \mathrm{a}^{\mathrm{a}}\right), 4.27-4.26(\mathrm{~m}, 1 \mathrm{H}$, $\mathrm{FcH}), 4.24(\mathrm{t}, J=1.8 \mathrm{~Hz}, 1 \mathrm{H}, \mathrm{FcH}), 4.21(\mathrm{t}, J=2.5 \mathrm{~Hz}, 1 \mathrm{H}, \mathrm{FcH}), 4.12(\mathrm{~s}, 5 \mathrm{H}, \mathrm{FcH}), 3.89$ (d, $\left.J=7.5 \mathrm{~Hz}, 1 \mathrm{H}, \mathrm{H}_{2 " \mathrm{a}}\right), 3.87\left(\mathrm{~d}, J=7.5 \mathrm{~Hz}, 1 \mathrm{H}, \mathrm{H}_{2 " \mathrm{~b}}\right), 3.72\left(\mathrm{~d}, J=13.6 \mathrm{~Hz}, 1 \mathrm{H}, \mathrm{H}_{2 ' \mathrm{~b}}\right), 3.64(\mathrm{~d}, J$ $\left.=13.1 \mathrm{~Hz}, 1 \mathrm{H}, \mathrm{H}_{1^{\prime} \mathrm{a}}\right), 2.90\left(\mathrm{~d}, J=13.0 \mathrm{~Hz}, 1 \mathrm{H}, \mathrm{H}_{\mathrm{l}^{\prime} \mathrm{b}}\right), 2.12\left(\mathrm{~s}, 6 \mathrm{H}, \mathrm{Me}_{2}\right) ;{ }^{13} \mathrm{C} \mathrm{NMR}(150 \mathrm{MHz}$, $\left.\mathrm{CDCl}_{3}\right) \delta 159.6,142.0,129.6,126.2,123.5,111.1,83.7,77.4,71.9,71.8,69.7(5 \mathrm{C}), 67.1,57.7$, 47.5, 45.4, 44.3 (2C); HRMS (ESI $\left.{ }^{+}\right) \mathrm{m} / z$ calcd for $\mathrm{C}_{21} \mathrm{H}_{24} \mathrm{BrFeN}_{3} \mathrm{O}_{3}: 501.0350$, Found 502.0420 $[\mathrm{M}+\mathrm{H}]^{+} ;$HPLC purity $>97 \%\left(t_{\mathrm{R}}=3.88 \mathrm{~min}\right)$.

\section{$N$-2-Ferrocenemethyl $\alpha$-amino-o-cresol (9i)}

Brown solid. Yield: 293.5 mg (98\%). M.p.: 116.5 - $119.0{ }^{\circ} \mathrm{C} .{ }^{1} \mathrm{H}$ NMR $\left(600 \mathrm{MHz}, \mathrm{CDCl}_{3}\right) \delta$ 7.19 (br s, 1H, H5), 7.00 (d, $\left.J=7.3 \mathrm{~Hz}, 1 \mathrm{H}, \mathrm{H}_{6}\right), 6.86$ (d, $\left.J=7.9 \mathrm{~Hz}, 1 \mathrm{H}, \mathrm{H}_{3}\right), 6.79$ (br s, 1H, $\left.\mathrm{H}_{4}\right), 4.17(\mathrm{~s}, 2 \mathrm{H}, \mathrm{FcH}), 4.15(\mathrm{~s}, 2 \mathrm{H}, \mathrm{FcH}), 4.13(\mathrm{~s}, 5 \mathrm{H}, \mathrm{FcH}), 4.01\left(\mathrm{~s}, 2 \mathrm{H}, \mathrm{H}_{2}\right), 3.57\left(\mathrm{~s}, 2 \mathrm{H}, \mathrm{H}_{1^{\prime}}\right)$; ${ }^{13} \mathrm{C} \mathrm{NMR}\left(150 \mathrm{MHz}, \mathrm{CDCl}_{3}\right) \delta 158.6,128.8,128.5,122.4,119.1,116.5,85.1,68.6(5 \mathrm{C}), 68.5$ (2C), 68.2 (2C), 52.0, 47.5; HRMS (ESI $\left.{ }^{+}\right) \mathrm{m} / z$ calcd for $\mathrm{C}_{18} \mathrm{H}_{19} \mathrm{FeNO}$ : 462.1445, Found $463.1656[\mathrm{M}+\mathrm{H}]^{+}$; HPLC purity $>95 \%\left(t_{\mathrm{R}}=2.37 \mathrm{~min}\right)$.

\section{$N$-2-Ferrocenemethyl 4-bromo- $\alpha$-amino-o-cresol $(9 \mathrm{j})$}

Light orange solid. Yield: $180.0 \mathrm{mg}(97 \%)$. M.p.: 106.5 - $107.2{ }^{\circ} \mathrm{C} .{ }^{1} \mathrm{H}$ NMR $(600 \mathrm{MHz}$, $\left.\mathrm{CDCl}_{3}\right) \delta 7.24\left(\right.$ br s, $\left.1 \mathrm{H}, \mathrm{H}_{5}\right), 7.10\left(\right.$ br s, $\left.1 \mathrm{H}, \mathrm{H}_{3}\right), 6.72\left(\mathrm{br} \mathrm{s}, 1 \mathrm{H}, \mathrm{H}_{6}\right), 4.15(\mathrm{~s}, 4 \mathrm{H}, \mathrm{FcH}), 4.12$ (s, 5H, FcH), $3.95\left(\mathrm{~s}, 2 \mathrm{H}, \mathrm{H}_{2}{ }^{\prime}\right), 3.54\left(\mathrm{~s}, 2 \mathrm{H}, \mathrm{H}_{1^{\prime}}\right) ;{ }^{13} \mathrm{C} \mathrm{NMR}\left(150 \mathrm{MHz}, \mathrm{CDCl}_{3}\right) \delta 157.8,131.5$, 
131.2, 124.4, 118.4, 110.8, 84.7, 68.7 (5C), 68.5 (5C), 68.4 (2C), 51.4, 47.5; HRMS (ESI $\left.{ }^{+}\right) \mathrm{m} / \mathrm{z}$ calcd for $\mathrm{C}_{18} \mathrm{H}_{18} \mathrm{BrFeNO}$ : 398.9921, Found $399.9842[\mathrm{M}+\mathrm{H}]^{+}$; HPLC purity $>91 \%\left(t_{\mathrm{R}}=5.03\right.$ $\min )$.

\section{$N$-2-Ferrocenemethyl 6-nitro- $\alpha$-amino-o-cresol (9k)}

Light green semi-solid. Yield: $130.0 \mathrm{mg}(96 \%) .{ }^{1} \mathrm{H}$ NMR (400 MHz, $\left.\mathrm{CDCl}_{3}\right) \delta 8.10(\mathrm{~d}, J=7.7$ $\left.\mathrm{Hz}, 1 \mathrm{H}, \mathrm{H}_{5}\right), 7.42\left(\mathrm{~d}, J=7.0 \mathrm{~Hz}, 1 \mathrm{H}, \mathrm{H}_{3}\right), 6.69\left(\mathrm{t}, J=7.5 \mathrm{~Hz}, 1 \mathrm{H}, \mathrm{H}_{4}\right), 4.59\left(\mathrm{~s}, 2 \mathrm{H}, \mathrm{H}_{2}\right), 4.24-$ $4.15(\mathrm{~m}, 9 \mathrm{H}, \mathrm{FcH}), 3.32\left(\mathrm{~s}, 2 \mathrm{H}, \mathrm{H}_{1}\right) ;{ }^{13} \mathrm{C} \mathrm{NMR}\left(100 \mathrm{MHz}, \mathrm{CDCl}_{3}\right) \delta 163.9(2 \mathrm{C}), 138.3,131.6$, 120.0, 114.4, 81.8, 69.0 (6C), 68.5, 54.4, 42.4; HRMS $\left(\mathrm{ESI}^{+}\right) \mathrm{m} / \mathrm{z}$ calcd for $\mathrm{C}_{18} \mathrm{H}_{18} \mathrm{FeN}_{2} \mathrm{O}_{3}$ : 366.0667, Found $367.0753[\mathrm{M}+\mathrm{H}]^{+}$; HPLC purity $>87 \%\left(t_{\mathrm{R}}=3.99 \mathrm{~min}\right)$.

\section{$N$-2-Ferrocenemethyl 4,6-dibromo- $\alpha$-amino-o-cresol (91)}

Brown semi-solid. Yield: $314.8 \mathrm{mg}(71 \%) .{ }^{1} \mathrm{H} \mathrm{NMR}\left(600 \mathrm{MHz}, \mathrm{CDCl}_{3}\right) \delta 7.55$ (br s, $\left.1 \mathrm{H}, \mathrm{H}_{3}\right)$, 7.05 (br s, 1H, H5), 4.18 (s, 2H, FcH), 4.16 (s, 2H, FcH), 4.13 (s, 5H, FcH), 3.96 (s, 2H, $\mathrm{H}_{2^{\prime}}$ ), $3.56\left(\mathrm{~s}, 2 \mathrm{H}, \mathrm{H}_{1^{\prime}}\right) ;{ }^{13} \mathrm{C} \mathrm{NMR}\left(150 \mathrm{MHz}, \mathrm{CDCl}_{3}\right) \delta 160.7,135.1,133.5,120.3,1192.3,110.0$, 84.9, 68.8 (5C), 68.2 (2C), 68.0 (2C), 57.9, 48.7; HRMS (ESI $\left.{ }^{+}\right) \mathrm{m} / z$ calcd for $\mathrm{C}_{18} \mathrm{H}_{17} \mathrm{Br}_{2} \mathrm{FeNO}$ : 476.9026, Found 477.9099 $[\mathrm{M}+\mathrm{H}]^{+} ;$HPLC purity $>85 \%\left(t_{\mathrm{R}}=6.99 \mathrm{~min}\right)$.

\section{$N$-2-Ferrocenemethyl 6-bromo-4-nitro- $\alpha$-amino-o-cresol (9m)}

Light brown semi-solid. Yield: $241.8 \mathrm{mg}(82 \%) .{ }^{1} \mathrm{H}$ NMR (600 MHz, DMSO- $\left.d_{6}\right) \delta 8.49(\mathrm{~d}, J$ $\left.=2.9 \mathrm{~Hz}, 1 \mathrm{H}, \mathrm{H}_{5}\right), 8.41\left(\mathrm{~d}, J=2.9 \mathrm{~Hz}, 1 \mathrm{H}, \mathrm{H}_{3}\right), 4.63\left(\mathrm{~s}, 2 \mathrm{H}, \mathrm{H}_{2^{\prime}}\right), 4.33(\mathrm{t}, J=1.8 \mathrm{~Hz}, 2 \mathrm{H}, \mathrm{FcH})$, $4.27(\mathrm{~s}, 5 \mathrm{H}, \mathrm{FcH}), 4.24(\mathrm{t}, J=1.8 \mathrm{~Hz}, 2 \mathrm{H}, \mathrm{FcH}), 4.21\left(\mathrm{~s}, 2 \mathrm{H}, \mathrm{H}_{1^{\prime}}\right) ;{ }^{13} \mathrm{C} \mathrm{NMR}(150 \mathrm{MHz}, \mathrm{DMSO})$ $\delta 167.1,133.1,132.6,131.4,118.3,111.8,82.0,69.4(2 \mathrm{C}), 68.7$ (5C), $68.5(2 \mathrm{C}), 68.0,50.0$; HRMS $\left(\mathrm{ESI}^{+}\right) \mathrm{m} / \mathrm{z}$ calcd for $\mathrm{C}_{18} \mathrm{H}_{17} \mathrm{BrFeN}_{2} \mathrm{O}_{3}$ : 443.9772, Found $444.9872[\mathrm{M}+\mathrm{H}]^{+}$; HPLC purity $>86 \%\left(t_{\mathrm{R}}=2.05 \mathrm{~min}\right)$. 


\section{$N$-((N,N-Dimethylamino)methyl)ferrocenemethyl)methyl benzylamine (12a)}

Brown semi-solid. Yield: $384.0 \mathrm{mg}(97 \%) .{ }^{1} \mathrm{H} \mathrm{NMR}\left(600 \mathrm{MHz}, \mathrm{CDCl}_{3}\right) \delta 7.32-7.31$ (m, 4H, $\left.\mathrm{H}_{2}, \mathrm{H}_{3}\right), 7.26-7.23\left(\mathrm{~m}, 1 \mathrm{H}, \mathrm{H}_{4}\right), 4.19$ (s, 1H, FcH), 4.10 (s, 1H, FcH), 4.04 (s, 1H, FcH), 4.02 (s, 5H, FcH), $3.84-3.78$ (m, 2H, H 2'a $^{\prime}, \mathrm{H}_{2 " \mathrm{a}}$ ), 3.70 (d, $\left.J=13.1 \mathrm{~Hz}, 1 \mathrm{H}, \mathrm{H}_{2 " \mathrm{~b}}\right), 3.64$ (d, J = 12.9 $\left.\mathrm{Hz}, \mathrm{H}_{1^{\prime} \mathrm{a}}\right), 3.37\left(\mathrm{~d}, J=13.1 \mathrm{~Hz}, 1 \mathrm{H}, \mathrm{H}_{2^{\prime} \mathrm{b}}\right), 2.81\left(\mathrm{~d}, J=13.0 \mathrm{~Hz}, 1 \mathrm{H}, \mathrm{H}_{1^{\prime} \mathrm{b}}\right), 2.09$ (s, 6H, NMe $)$; ${ }^{13} \mathrm{C}$ NMR (150 MHz, $\left.\mathrm{CDCl}_{3}\right) \delta 139.5,128.5$ (2C), 128.4 (2C), 127.0 (2C), 85.3, 71.1, 70.3, 69.0 (5C), 66.1, 58.0, 52.6, 46.9, 44.9 (2C); HRMS (ESI ${ }^{+}$) $m / z$ calcd for $\mathrm{C}_{21} \mathrm{H}_{26} \mathrm{FeN}_{2}$ : 362.1445, Found $363.1527[\mathrm{M}+\mathrm{H}]^{+}$; HPLC purity $>87 \%\left(t_{\mathrm{R}}=4.59 \mathrm{~min}\right)$.

\section{$N$-((N,N-Dimethylamino)methyl)ferrocenemethyl)methyl 2-methoxybenzylamine (12b)}

Orange viscous oil. Yield: $45 \mathrm{mg}(34 \%) .{ }^{1} \mathrm{H} \mathrm{NMR}\left(400 \mathrm{MHz}, \mathrm{CDCl}_{3}\right) \delta 6.77-6.53(\mathrm{~m}, 3 \mathrm{H}$,

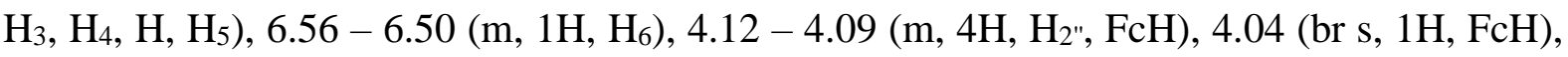
$4.02(\mathrm{~s}, 5 \mathrm{H}, \mathrm{FcH}), 3.82-3.78\left(\mathrm{~m}, 2 \mathrm{H}, \mathrm{H}_{2}\right), 3.75(\mathrm{~s}, \mathrm{~Hz}, 3 \mathrm{H}, \mathrm{OMe}), 3.32(\mathrm{~d}, J=13.4 \mathrm{~Hz}, 1 \mathrm{H}$, $\left.\mathrm{H}_{1^{\prime} \mathrm{a}}\right), 2.76\left(\mathrm{~d}, J=12.0 \mathrm{~Hz}, 1 \mathrm{H}, \mathrm{H}_{1^{\prime} \mathrm{b}}\right), 2.11\left(\mathrm{~s}, 6 \mathrm{H}, \mathrm{NMe}_{2}\right) ;{ }^{13} \mathrm{C} \mathrm{NMR}\left(100 \mathrm{MHz}, \mathrm{CDCl}_{3}\right) \delta 168.8$, $157.7,129.9,128.4,120.5,110.3,84.0,83.6,70.8,69.4,69.1$ (5C), 69.0, 66.2, 57.9, 55.4, 50.4, 45.0 (2C); HRMS $\left(\mathrm{ESI}^{+}\right) \mathrm{m} / \mathrm{z}$ calcd for $\mathrm{C}_{22} \mathrm{H}_{28} \mathrm{FeN}_{2} \mathrm{O}: 393.1622$, Found 393.1623 [M] ${ }^{+}$; HPLC purity $>95 \%\left(t_{\mathrm{R}}=5.12 \mathrm{~min}\right)$.

\section{$N-((N, N$-Dimethylamino)methyl)ferrocenemethyl)methyl 2-nitrobenzylamine (12c)}

Brown semi-solid. Yield: $124.2 \mathrm{mg}(59 \%) .{ }^{1} \mathrm{H} \mathrm{NMR}\left(600 \mathrm{MHz}, \mathrm{CDCl}_{3}\right) \delta 7.94(\mathrm{~d}, J=8.1 \mathrm{~Hz}$, $\left.1 \mathrm{H}, \mathrm{H}_{3}\right), 7.66\left(\mathrm{~d}, J=7.7 \mathrm{~Hz}, 1 \mathrm{H}, \mathrm{H}_{6}\right), 7.58\left(\mathrm{t}, J=7.5 \mathrm{~Hz}, 1 \mathrm{H}, \mathrm{H}_{4}\right), 7.39\left(\mathrm{t}, J=7.7 \mathrm{~Hz}, 1 \mathrm{H}, \mathrm{H}_{5}\right)$, 4.19 (br s, 1H, FcH), $4.12-4.10(\mathrm{~m}, 1 \mathrm{H}, \mathrm{FcH}), 4.02$ (br s, 1H, FcH), $4.05-3.99$ (m, 7H, FcH, $\left.\mathrm{H}_{2^{\prime \prime}}\right), 3.76\left(\mathrm{~d}, J=12.9 \mathrm{~Hz}, 1 \mathrm{H}, \mathrm{H}_{2^{\prime} \mathrm{a}}\right), 3.61\left(\mathrm{~d}, J=12.6 \mathrm{~Hz}, 1 \mathrm{H}, \mathrm{H}_{1^{\prime}} \mathrm{a}\right), 3.37(\mathrm{~d}, J=12.9 \mathrm{~Hz}, 1 \mathrm{H}$, $\left.\mathrm{H}_{2}{ }^{\prime} \mathrm{b}\right), 2.83\left(\mathrm{~d}, J=12.6 \mathrm{~Hz}, 1 \mathrm{H}, \mathrm{H}_{1^{\prime} \mathrm{b}}\right), 2.09\left(\mathrm{~s}, 6 \mathrm{H}, \mathrm{NMe}_{2}\right) ;{ }^{13} \mathrm{C} \mathrm{NMR}\left(150 \mathrm{MHz}, \mathrm{CDCl}_{3}\right) \delta 149.1$, $136.1,133.2,130.8,127.7,124.7,86.2,83.6,71.1,69.9,69.0(5 C), 66.2,58.1,50.0,47.7,45.0$ 
(2C); HRMS $\left(\mathrm{ESI}^{+}\right) \mathrm{m} / z$ calcd for $\mathrm{C}_{21} \mathrm{H}_{25} \mathrm{FeN}_{3} \mathrm{O}_{2}$ : 407.1296, Found 408.1369 [M+H] $]^{+}$; HPLC purity $>92 \%\left(t_{\mathrm{R}}=7.18 \mathrm{~min}\right)$.

\section{$N$-((N,N-Dimethylamino)methyl)ferrocenemethyl)methyl 2-aminobenzylamine $(12 \mathrm{~d})^{[27]}$}

A mixture of 2-nitrobenzylamine 12c $(95.0 \mathrm{mg})$, zinc dust $(126.0 \mathrm{mg})$ and ammonium chloride $(25.0 \mathrm{mg})$ in methanol $(10 \mathrm{~mL})$ was refluxed for 12 hours. Following reflux, the solids were removed through a small pad of silica gel using 1:1 methanol/DCM as an eluent and the filtrate collected and concentrated in vacuo. The resulting residue was re-dissolved in EtOAc $(25 \mathrm{~mL})$ and then successively washed with saturated $\mathrm{NaHCO}_{3}$ solution and water. The collected organic layer was dried $\left(\mathrm{Na}_{2} \mathrm{SO}_{3}\right)$ and the solvent removed under reduced pressure to afford the desired compound as a yellow semi-solid in high purity. Yield: $86.0 \mathrm{mg}(98 \%) .{ }^{1} \mathrm{H}$ NMR $\left(600 \mathrm{MHz}, \mathrm{CDCl}_{3}\right) \delta 8.69\left(\mathrm{~d}, J=9.0 \mathrm{~Hz}, 1 \mathrm{H}, \mathrm{H}_{3}\right), 7.65\left(\mathrm{~d}, J=8.4 \mathrm{~Hz}, 1 \mathrm{H}, \mathrm{H}_{4}\right), 7.43-7.40(\mathrm{~m}$, 1H, H5), $7.20-7.16\left(\mathrm{~m}, 1 \mathrm{H}, \mathrm{H}_{6}\right), 6.55\left(\mathrm{~d}, J=12.1 \mathrm{~Hz}, 1 \mathrm{H}, \mathrm{H}_{2 " \mathrm{a}}\right), 5.34(\mathrm{~d}, J=12.1 \mathrm{~Hz}, 1 \mathrm{H}$, $\left.\mathrm{H}_{2 " \mathrm{~b}}\right), 4.78\left(\mathrm{~d}, J=13.0 \mathrm{~Hz}, 1 \mathrm{H}, \mathrm{H}_{2^{\prime} \mathrm{a}}\right), 4.25-4.24(\mathrm{~m}, 6 \mathrm{H}, \mathrm{FcH}), 4.21$ (br s, 1H, FcH), 4.17 (t, $J$ $=2.5 \mathrm{~Hz}, 1 \mathrm{H}, \mathrm{FcH}), 4.13-4.10\left(\mathrm{~m}, 1 \mathrm{H}, \mathrm{H}_{2^{\prime} \mathrm{b}}\right), 3.08\left(\mathrm{~d}, J=13.0 \mathrm{~Hz}, 1 \mathrm{H}, \mathrm{H}_{1^{\prime} \mathrm{a}}\right), 2.71-2.70(\mathrm{~m}$, $\left.1 \mathrm{H}, \mathrm{H}_{1^{\prime} \mathrm{b}}\right), 2.29-2.20\left(\mathrm{~m}, 6 \mathrm{H}, \mathrm{NMe}_{2}\right) ;{ }^{13} \mathrm{C} \mathrm{NMR}\left(150 \mathrm{MHz}, \mathrm{CDCl}_{3}\right) \delta$ 129.6, 127.3, 123.6, $121.5,120.3,117.5,82.6,79.4,73.6,70.0,69.8$ (5C), 69.4, 58.4, 51.8, 49.2, 43.3 (2C); HRMS $\left(\mathrm{ESI}^{+}\right) \mathrm{m} / z$ calcd for $\mathrm{C}_{21} \mathrm{H}_{27} \mathrm{FeN}_{3}: 377.1554$, Found $378.1629[\mathrm{M}+\mathrm{H}]^{+}$; HPLC purity $>83 \%\left(t_{\mathrm{R}}\right.$ $=4.11 \mathrm{~min})$.

\section{General procedure for the synthesis of ferrocenyl salicylamides (14a-g) ${ }^{[28]}$}

A suspension of an appropriate ferrocenyl amine 7a-b (1.0 eq.), substituted salicylic acid 13af (1.0 eq.) and DCC (1.2 eq.) pyridine $(15 \mathrm{~mL})$ was heated in a monowave microwave reactor at $80{ }^{\circ} \mathrm{C}$ for 2 hours. After completion of the reaction, the formed dark brown suspension was kept on ice for 10 minutes, diluted with EtOAc $(25 \mathrm{~mL})$ and then filtered through celite to remove the urea precipitate. The filtrate was dried under reduced pressure to give a crude 
residue, which was subjected to silica gel column chromatography to afford the pure salicylamide product.

\section{$N$-(N,N-Dimethylamino)methyl)ferrocenemethyl salicylamide (14a)}

Light brown semi-solid. Yield: $132.0 \mathrm{mg}(92 \%) .{ }^{1} \mathrm{H}$ NMR (400 MHz, $\left.\mathrm{CDCl}_{3}\right) \delta 7.26-7.19$ (m, 2H, H3, $\left.\mathrm{H}_{4}\right), 6.87$ (t, $\left.J=8.2 \mathrm{~Hz}, 1 \mathrm{H}, \mathrm{H}_{5}\right), 6.69$ (br s, 1H, $\left.\mathrm{H}_{6}\right), 4.68\left(\mathrm{~d}, J=13.1 \mathrm{~Hz}, 1 \mathrm{H}, \mathrm{H}_{2}{ }^{\prime}\right.$ ) $4.23-4.16(\mathrm{~m}, 2 \mathrm{H}, \mathrm{FcH}), 4.06(\mathrm{~s}, 5 \mathrm{H}, \mathrm{FcH}), 3.99-3.94\left(\mathrm{~m}, 2 \mathrm{H}, \mathrm{FcH}, \mathrm{H}_{2} \mathrm{~b}\right), 3.10-3.04$ (m, $\left.1 \mathrm{H}, \mathrm{H}_{1^{\prime} \mathrm{a}}\right), 2.83-2.79\left(\mathrm{~m}, 1 \mathrm{H}, \mathrm{H}_{1^{\prime} \mathrm{b}}\right), 2.19\left(\mathrm{~s}, 6 \mathrm{H}, \mathrm{NMe}_{2}\right) ;{ }^{13} \mathrm{C} \mathrm{NMR}\left(100 \mathrm{MHz}, \mathrm{CDCl}_{3}\right) \delta 169.2$, 161.8, 133.6, 125.7, 118.3, 118.2, 114.8, 83.9, 71.3, 70.4, 69.6, 69.3 (5C), 66.0, 44.8, 38.3, 29.7 (2C); HRMS (ESI $\left.{ }^{+}\right) \mathrm{m} / z$ calcd for $\mathrm{C}_{21} \mathrm{H}_{24} \mathrm{FeN}_{2} \mathrm{O}_{2}: 392.1187$, Found $393.1295[\mathrm{M}+\mathrm{H}]^{+}$; HPLC purity $>80 \%\left(t_{\mathrm{R}}=4.09 \mathrm{~min}\right)$.

\section{$N$-(N,N-Dimethylamino)methyl)ferrocenemethyl-5-chlorosalicylamide (14b)}

Light yellow semi-solid. Yield: $149.0 \mathrm{mg}(95 \%) .{ }^{1} \mathrm{H}$ NMR $\left(600 \mathrm{MHz}, \mathrm{CDCl}_{3}\right) \delta 7.26-7.25$ (m, 2H, H, H4 $\left.\mathrm{H}_{6}\right), 6.88\left(\mathrm{~d}, J=9.0 \mathrm{~Hz}, 1 \mathrm{H}, \mathrm{H}_{3}\right), 4.71\left(\mathrm{~d}, J=14.4 \mathrm{~Hz}, 1 \mathrm{H}, \mathrm{H}_{2^{\prime} \mathrm{a}}\right), 4.24$ (br s, 1H, $\mathrm{FcH}), 4.21\left(\mathrm{~d}, J=14.4 \mathrm{~Hz}, 1 \mathrm{H}, \mathrm{H}_{2} \mathrm{~b}\right), 4.14(\mathrm{br} \mathrm{s}, 1 \mathrm{H}, \mathrm{FcH}), 4.11(\mathrm{~s}, 5 \mathrm{H}, \mathrm{FcH}), 4.05(\mathrm{t}, J=2.4$ $\mathrm{Hz}, 1 \mathrm{H}, \mathrm{FcH}), 3.86\left(\mathrm{~d}, J=12.7 \mathrm{~Hz}, 1 \mathrm{H}, \mathrm{H}_{1^{\prime} \mathrm{a}}\right), 2.89$ (d, $\left.J=12.7 \mathrm{~Hz}, 1 \mathrm{H}, \mathrm{H}_{1^{\prime} \mathrm{b}}\right), 2.29$ (s, 6H, $\left.\mathrm{NMe}_{2}\right) ;{ }^{13} \mathrm{C} \mathrm{NMR}\left(150 \mathrm{MHz}, \mathrm{CDCl}_{3}\right) \delta 168.0,160.4,133.4,125.8,123.0,119.9,115.8,83.8$, 83.7, 71.6, 70.5, 69.4 (5C), 66.1, 58.4, 44.7 (2C), 38.7; HRMS (ESI $\left.{ }^{+}\right) \mathrm{m} / z$ calcd for $\mathrm{C}_{21} \mathrm{H}_{23} \mathrm{ClFeN}_{2} \mathrm{O}_{2}: 426.0797$, Found $427.0874[\mathrm{M}+\mathrm{H}]^{+} ;$HPLC purity $>93 \%\left(t_{\mathrm{R}}=4.09 \mathrm{~min}\right)$.

\section{$N$-(N,N-Dimethylamino)methyl)ferrocenemethyl-5-nitrosalicylamide (14c)}

Yellow semi-solid. Yield: $125.1 \mathrm{mg}(78 \%) .{ }^{1} \mathrm{H}$ NMR $\left(600 \mathrm{MHz}, \mathrm{CDCl}_{3}\right) \delta 7.56-7.53(\mathrm{~m}, 2 \mathrm{H}$, $\left.\mathrm{H}_{4}, \mathrm{H}_{6}\right), 6.72\left(\mathrm{~d}, J=9.3 \mathrm{~Hz}, 1 \mathrm{H}, \mathrm{H}_{3}\right), 4.70\left(\mathrm{~d}, J=14.4 \mathrm{~Hz}, 1 \mathrm{H}, \mathrm{H}_{2^{\prime} \mathrm{a}}\right), 4.23$ (br s, $\left.1 \mathrm{H}, \mathrm{FcH}\right), 4.19$ $\left(\mathrm{d}, J=14.4 \mathrm{~Hz}, 1 \mathrm{H}, \mathrm{H}_{2 \mathrm{r}} \mathrm{b}\right), 4.14(\mathrm{br}, 1 \mathrm{H}, \mathrm{FcH}), 4.11(\mathrm{~s}, 5 \mathrm{H}, \mathrm{FcH}), 4.05(\mathrm{t}, J=2.4 \mathrm{~Hz}, 1 \mathrm{H}, \mathrm{FcH})$, $3.84\left(\mathrm{~d}, J=12.7 \mathrm{~Hz}, 1 \mathrm{H}, \mathrm{H}_{1^{\prime} \mathrm{a}}\right), 2.87\left(\mathrm{~d}, J=12.7 \mathrm{~Hz}, 1 \mathrm{H}, \mathrm{H}_{1^{\prime} \mathrm{b}}\right), 2.33\left(\mathrm{~s}, 6 \mathrm{H}, \mathrm{NMe}_{2}\right) ;{ }^{13} \mathrm{C} \mathrm{NMR}$ $\left(150 \mathrm{MHz}, \mathrm{CDCl}_{3}\right) \delta 168.0,137.6,128.9(2 \mathrm{C}), 124.2,120.1,114.7,83.9,81.9,71.4,70.6,69.5$ 
(5C), 66.8, 58.4, 44.2 (2C), 38.4; HRMS $\left(\mathrm{ESI}^{+}\right) \mathrm{m} / z$ calcd for $\mathrm{C}_{21} \mathrm{H}_{23} \mathrm{FeN}_{3} \mathrm{O}_{4}$ : 437.1038, Found $438.1120[\mathrm{M}+\mathrm{H}]^{+} ;$HPLC purity $>97 \%\left(t_{\mathrm{R}}=2.83 \mathrm{~min}\right)$.

\section{$N$-(N,N-Dimethylamino)methyl)ferrocenemethyl-4-fluorosalicylamide (14d)}

Light orange semi-solid. Yield: $123.4 \mathrm{mg}(82 \%) .{ }^{1} \mathrm{H}$ NMR (600 MHz, $\left.\mathrm{CDCl}_{3}\right) \delta 7.26-7.19$ $\left(\mathrm{m}, 1 \mathrm{H}, \mathrm{H}_{3}\right), 6.61\left(\mathrm{dd}, J=10.5,2.3 \mathrm{~Hz}, 1 \mathrm{H}, \mathrm{H}_{6}\right), 6.46\left(\mathrm{td}, J=8.6,2.3 \mathrm{~Hz}, 1 \mathrm{H}, \mathrm{H}_{5}\right), 4.71(\mathrm{~d}, J=$

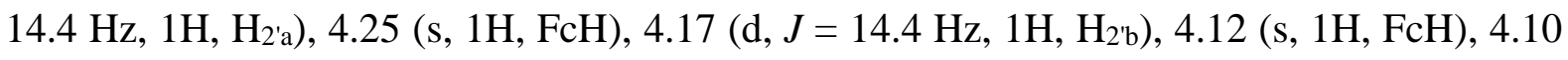
(s, 5H, FcH), $4.04(\mathrm{~s}, 1 \mathrm{H}, \mathrm{FcH}), 3.85\left(\mathrm{~d}, J=12.7 \mathrm{~Hz}, 1 \mathrm{H}, \mathrm{H}_{1^{\prime} \mathrm{a}}\right), 2.88\left(\mathrm{~d}, J=12.7 \mathrm{~Hz}, 1 \mathrm{H}, \mathrm{H}_{1^{\prime} \mathrm{b}}\right)$, $2.23\left(\mathrm{~s}, 6 \mathrm{H}, \mathrm{NMe}_{2}\right) ;{ }^{13} \mathrm{C} \mathrm{NMR}\left(150 \mathrm{MHz}, \mathrm{CDCl}_{3}\right) \delta 168.6,165.9(\mathrm{~d}, J=251.7 \mathrm{~Hz}), 164.0(\mathrm{~d}, J$ $=13.6 \mathrm{~Hz}), 127.6(\mathrm{~d}, J=11.1 \mathrm{~Hz}), 111.6,106.1(\mathrm{~d}, J=22.6 \mathrm{~Hz}), 104.9(\mathrm{~d}, J=23.3 \mathrm{~Hz}), 83.9$ (2C), 71.4, 70.5, 69.4 (5C), 66.2, 58.2, 44.8 (2C), 38.4; HRMS (ESI ${ }^{+}$m/z calcd for $\mathrm{C}_{21} \mathrm{H}_{23} \mathrm{FeN}_{2} \mathrm{O}_{2}: 410.1093$, Found $410.1010[\mathrm{M}]^{+}$; HPLC purity $>99 \%\left(t_{\mathrm{R}}=3.88 \mathrm{~min}\right)$.

\section{$N$-(N,N-Dimethylamino)methyl)ferrocenemethyl-2-hydroxynicotinamide (14e)}

Light brown semi-solid. Yield: $99.6 \mathrm{mg}(69 \%) .{ }^{1} \mathrm{H} \mathrm{NMR}\left(600 \mathrm{MHz}, \mathrm{CDCl}_{3}\right) \delta 9.84(\mathrm{~s}, 1 \mathrm{H}$, $\mathrm{NH}), 8.56\left(\mathrm{~d}, J=7.1 \mathrm{~Hz}, 1 \mathrm{H}, \mathrm{H}_{6}\right), 7.30-7.25\left(\mathrm{~m}, 1 \mathrm{H}, \mathrm{H}_{4}\right), 6.41\left(\mathrm{t}, J=6.8 \mathrm{~Hz}, 1 \mathrm{H}, \mathrm{H}_{5}\right), 4.49$ $\left(\mathrm{dd}, J=15.0,5.7 \mathrm{~Hz}, 1 \mathrm{H}, \mathrm{H}_{2^{\prime} \mathrm{a}}\right), 4.31\left(\mathrm{dd}, J=15.0,3.8 \mathrm{~Hz}, 1 \mathrm{H}, \mathrm{H}_{2^{\prime} \mathrm{b}}\right), 4.24$ (br s, 1H, FcH), 4.23 (br s, 1H, FcH), $4.16(\mathrm{~s}, 5 \mathrm{H}, \mathrm{FcH}), 4.10(\mathrm{t}, J=2.1 \mathrm{~Hz}, 1 \mathrm{H}, \mathrm{FcH}), 3.51(\mathrm{~d}, J=13.0 \mathrm{~Hz}, 1 \mathrm{H}$, $\left.\mathrm{H}_{1^{\prime} \mathrm{a}}\right), 3.31\left(\mathrm{~d}, J=13.0 \mathrm{~Hz}, 1 \mathrm{H}, \mathrm{H}_{1^{\prime} \mathrm{b}}\right), 2.20\left(\mathrm{~s}, 6 \mathrm{H}, \mathrm{NMe}_{2}\right) ;{ }^{13} \mathrm{C} \mathrm{NMR}\left(150 \mathrm{MHz}, \mathrm{CDCl}_{3}\right) \delta 163.8$, $163.5,145.3,138.1,121.3,107.7,85.3,82.4,70.7,69.3,68.5(2 C), 67.1,57.1,44.8(2 C), 37.7$; HRMS $\left(\mathrm{ESI}^{+}\right) \mathrm{m} / \mathrm{z}$ calcd for $\mathrm{C}_{20} \mathrm{H}_{23} \mathrm{FeN}_{3} \mathrm{O}_{2}: 393.1140$, Found 394.1221 [M+H] $]^{+}$; HPLC purity $>98 \%\left(t_{\mathrm{R}}=3.50 \mathrm{~min}\right)$.

\section{$N$-Ferrocenemethylsalicylamide (14f)}

Orange semi-solid. Yield: $218.2 \mathrm{mg}(70 \%) .{ }^{1} \mathrm{H} \mathrm{NMR}\left(400 \mathrm{MHz}, \mathrm{CDCl}_{3}\right) \delta 12.37$ (br s, $1 \mathrm{H}$, $\mathrm{OH}), 7.40\left(\mathrm{t}, J=8.4 \mathrm{~Hz}, 1 \mathrm{H}, \mathrm{H}_{4}\right), 7.32\left(\mathrm{~d}, J=8.0 \mathrm{~Hz}, 1 \mathrm{H}, \mathrm{H}_{6}\right), 7.00\left(\mathrm{~d}, J=8.3 \mathrm{~Hz}, 1 \mathrm{H}, \mathrm{H}, \mathrm{H}_{3}\right)$, $6.84\left(\mathrm{t}, J=7.9 \mathrm{~Hz}, 1 \mathrm{H}, \mathrm{H}_{5}\right), 6.49(\mathrm{br} \mathrm{s}, 1 \mathrm{H}, \mathrm{NH}), 4.32\left(\mathrm{~d}, J=5.1 \mathrm{~Hz}, 2 \mathrm{H}, \mathrm{H}_{1^{\prime}}\right), 4.26-4.25$ (m, 
$2 \mathrm{H}, \mathrm{FcH}), 4.21(\mathrm{~s}, 5 \mathrm{H}, \mathrm{FcH}), 4.20-4.18(\mathrm{~m}, 2 \mathrm{H}, \mathrm{FcH}) ;{ }^{13} \mathrm{C} \mathrm{NMR}\left(100 \mathrm{MHz}, \mathrm{CDCl}_{3}\right) \delta 169.3$, 161.7, 134.3, 125.2, 118.8 (2C), 114.2, 84.1, 68.7 (2C), 68.5 (7C), 39.1; HRMS (ESI $\left.{ }^{+}\right) \mathrm{m} / \mathrm{z}$ calcd for $\mathrm{C}_{18} \mathrm{H}_{17} \mathrm{FeNO}_{2}: 335.0609$, Found $335.0601[\mathrm{M}]^{+}$; HPLC purity $>99 \%\left(t_{\mathrm{R}}=2.14 \mathrm{~min}\right)$.

\section{$N$-Ferrocenemethylthiosalicylamide (14g)}

Brown semi-solid. Yield: 222.1 mg (68\%). ${ }^{1} \mathrm{H}$ NMR $\left(600 \mathrm{MHz}, \mathrm{CDCl}_{3}\right) \delta 8.02(\mathrm{~d}, J=7.8 \mathrm{~Hz}$, $\left.1 \mathrm{H}, \mathrm{H}_{6}\right), 7.55\left(\mathrm{t}, J=7.4 \mathrm{~Hz}, 1 \mathrm{H}, \mathrm{H}_{4}\right), 7.46\left(\mathrm{~d}, J=8.0 \mathrm{~Hz}, 1 \mathrm{H}, \mathrm{H}_{3}\right), 7.36\left(\mathrm{t}, J=7.4 \mathrm{~Hz}, 1 \mathrm{H}, \mathrm{H}_{5}\right)$, $4.82\left(\mathrm{~s}, 2 \mathrm{H}, \mathrm{H}_{1^{\prime}}\right), 4.33$ (s, 2H, FcH), 4.21 (s, 5H, FcH), 4.19 (s, 2H, FcH); ${ }^{13} \mathrm{C}$ NMR $(150 \mathrm{MHz}$, $\left.\mathrm{CDCl}_{3}\right) \delta 164.9,140.4,131.7,126.8,125.5,124.9,120.4,82.1,69.6$ (2C), 69.0 (7C), 43.6; HRMS $\left(\mathrm{ESI}^{+}\right) \mathrm{m} / z$ calcd for $\mathrm{C}_{18} \mathrm{H}_{17} \mathrm{FeNOS}$ : 351.0380, Found 351.0269 [M] ${ }^{+}$; HPLC purity > $99 \%\left(t_{\mathrm{R}}=3.37 \mathrm{~min}\right)$.

\section{D7 Plasmodium falciparum antiplasmodial assay}

The malaria parasites (3D7 P. falciparum strain) were cultured in a medium RPMI1640 containing 25 mM L-glutamine, 25 mM HEPES (Lonza, Switzerland), 0.5\% (w/v) albumax II (Thermo Fisher Scientific, Waltham, MA), $20 \mathrm{mM}$ glucose, $0.65 \mathrm{mM}$ hypoxanthine, $60 \mu \mathrm{g} / \mathrm{mL}$ gentamicin and $2-4 \%(\mathrm{v} / \mathrm{v})$ hematocrit erythrocytes. The cultures were maintained at $37^{\circ} \mathrm{C}$ under an atmosphere of $5 \% \mathrm{CO}_{2}, 5 \% \mathrm{O}_{2}$ and $90 \% \mathrm{~N}_{2}$, and then were treated with three-fold serial dilutions of the test compounds and chloroquine (control) in 96-well plates. The plates were incubated under the same conditions for 48 hours after which $20 \mu \mathrm{L}$ of the culture was removed from each well and transferred to a new plate. The transferred cultures were mixed with $125 \mu \mathrm{L}$ of a mixture of Malstat and nitroblue tetrazolium/phenazine ethosulfate solution to assess the activity of the plasmodium lactate dehydrogenase (pLDH) enzyme in the cultures by measuring absorbance at $620 \mathrm{~nm}$ on the SpectraMax M3 microplate reader (Molecular Devices, San Jose, CA, USA). To quantify the antiplasmodial activity of the compounds, the recorded absorbance of the formed purple product in each well was plotted against the 
logarithm of the corresponding compound concentration in GraphPad Prism 5.02 software and the plasmocidal activities were reported as half-maximal inhibitory concentration $\left(\mathrm{IC}_{50}\right)$ by non-linear regression analysis. ${ }^{[62]}$ The activity was determined in duplicate for each compound.

\section{Dd2 Plasmodium falciparum antiplasmodial assay}

Cultures of the Dd2 P. falciparum strain were prepared and maintained in an Albumax IIcontaining medium (Thermo Fisher Scientific, South Africa) according to a modified procedure by Trager and Jensen, keeping the hematocrit concentration at 4\%. ${ }^{[63]}$ Upon reaching the trophozoite stage, the cultures were seeded in 96-well plates and incubated with varying concentrations of the test compounds $(0-10 \mu \mathrm{M})$ and controls (chloroquine and artemisinin). The plates were incubated for 48 hours under an atmosphere containing $4 \% \mathrm{CO}_{2}$ and $3 \% \mathrm{O}_{2}$ in nitrogen at $37^{\circ} \mathrm{C}$. The $\mathrm{pLDH}$ procedure was employed to determine the antiplasmodial activity of the compounds in triplicate as previously reported. ${ }^{[64-65]}$

\section{HeLa assay for preliminary cytotoxicity testing}

Cultures of HeLa cells (Cellonex, South Africa) were grown in Dulbecco's Modified Eagle's medium (Lonza, Switzerland) containing 10\% foetal calf serum and antibiotics (penicillin, streptomycin and amphotericin B) in a 5\% $\mathrm{CO}_{2}$ incubator maintained at $37{ }^{\circ} \mathrm{C}$. The cells were seeded in a 96-well pate and incubated for 24 hours. After incubation, the test compounds were added to the seeded cells in the wells to a final concentration of $20 \mu \mathrm{M}$ and further incubated for 48 hours under the same conditions. The viability of the cells in each well was determined using the resazurin procedure previously reported by reading the resorufin fluorescence in a SpectraMax M3 microplate reader. ${ }^{[36]}$

\section{HCC70 breast cancer cell line antiproliferative assay}

The HCC70 human triple-negative breast cancer cells were cultured in RPMI media supplemented with $10 \%$ (v/v) foetal bovine serum (FBS), $1 \mathrm{mM} \mathrm{L-glutamine,} 100 \mathrm{U} / \mathrm{mL}$ 
penicillin, $100 \mu \mathrm{g} / \mathrm{mL}$ streptomycin and $12.5 \mu \mathrm{g} / \mathrm{mL}$ amphotericin (PSA) and were maintained at $37{ }^{\circ} \mathrm{C}$ in a $9 \% \mathrm{CO}_{2}$ atmosphere. The cells were seeded in 96-well plates with cell density adjusted to $5 \times 10^{3}$ cells/well and allowed to adhere to the plate overnight. A concentration range $(0-1000 \mu \mathrm{M})$ of either the paclitaxel (positive control) or test compounds in DMSO was added to the seeded cell and incubated for 72 hours under the same atmosphere. The antiproliferative activity of the compounds was determined using a previously described resazurin assay. ${ }^{[23]}$ $\mathrm{IC}_{50}$ values were calculated by non-linear regression using GraphPad Prism 4.0 software.

\section{UV-Vis DNA titration experiment}

A concentration range of $0-100 \mu \mathrm{M}$ of the test compounds $(\mathbf{9 a}, \mathbf{9 b}, \mathbf{9 j}, \mathbf{1 2} \mathbf{a}$ and $\mathbf{1 4 a})$ prepared from a $20 \mathrm{mM}$ stock solution in DMSO using milli-Q water were added to a solution of calf thymus DNA (70 ng/ $\mu \mathrm{L})$ in a $96-w e l l$ pate and incubated at $37^{\circ} \mathrm{C}$ for 15 minutes. Following incubation, the absorbance of the samples in each well was monitored between 230 and 290 nm on a SpectraMax M3 microplate plate reader (Molecular Devices, San Jose, CA, USA). The absorbance of a $100 \mu \mathrm{M}$ sample of each test compound was also recorded in the same wavelength range. To assess the binding affinity of the compounds for DNA, the concentrationdependent response curves of the samples were plotted as spectra depicting absorbance measured over wavelengths from 230 to $290 \mathrm{~nm}$. The binding affinity of the compounds was determined in terms of the binding constant as the ratio of intercept to slope of the reciprocal guest-host plot correlating maximum absorbance (around $260 \mathrm{~nm}$ ) to compound concentration.

\section{Competitive DNA binding studies}

A solution of Hoechst $33342(1 \mu \mathrm{g} / \mathrm{mL})$ or methylene blue $(1.5 \mu \mathrm{g} / \mathrm{mL})$ was added to a solution of calf thymus DNA ( $70 \mu \mathrm{g} / \mathrm{mL}$ ) containing 0 (i.e., DMSO), 50 or $100 \mu \mathrm{M}$ of test compounds 9a and 9j in milli-Q water. The samples were allowed to equilibrate in the dark at room temperature for 15 minutes after which fluorescence spectra were recorded (excitation: 350 
nm, emission: $400-600 \mathrm{~nm}$ for Hoechst 33342 and excitation: $665 \mathrm{~nm}$, emission: 650 - 750 $\mathrm{nm}$ for methylene blue). A $100 \mu \mathrm{M}$ sample of cisplatin prepared similarly to the test sample was employed as a positive control in the competitive methylene blue intercalation study.

\section{Selective DNA binding assay between malarial and mammalian DNA}

The selective binding assay was carried out as described for the Hoechst assay above using 15 $\mu \mathrm{M}$ of compound 9a, $2.5 \mathrm{ng} / \mu \mathrm{L}$ calf-thymus DNA and $2.5 \mathrm{ng} / \mu \mathrm{L}$ DNA isolated from the 3D7 P. falciparum. Isolation of the malarial DNA was accomplished with the Quick-DNA Miniprep Kit (\#D3024/D3025) (Zymo Research, Irvine, CA, USA) according to the manufacturer's instructions and literature methods using 3D7 P. falciparum trophozoites cultured similarly to those employed in the 3D7 antiplasmodial evaluation assay as a DNA source. ${ }^{[66]}$

\section{$\beta$-Hematin binding assay}

Hemozoin inhibitory assay was performed according the procedure reported by Egan and coworkers with minor modifications. ${ }^{[38]}$ A $25 \mu \mathrm{M}$ stock solution of $\beta$-hematin was prepared by dissolving $25 \mathrm{mg}$ of hemin (from porcine) in $947 \mu \mathrm{L}$ of DMSO and sonicating the resulting suspension for 1 minute to ensure complete homogenization. A volume of $178 \mu \mathrm{M}$ of the hematin solution was added to $20 \mathrm{~mL}$ of $1.0 \mathrm{M}$ acetate buffer $(\mathrm{pH} 4.8)$ and thoroughly mixed to give a final concentration of $220 \mu \mathrm{M}$ hematin solution. Varying concentrations $(1-1000$ $\mu \mathrm{M})$ of the test compounds $(\mathbf{9 a}, \mathbf{9 b}, \mathbf{9 j}, \mathbf{1 2 a}$ and 14a) in DMSO were placed in a 96-well plate, keeping the total volume of DMSO below $10 \mu \mathrm{L}$ in each well. A sample of chloroquine was prepared similarly and used as a positive control in the assay, while DMSO was used as a negative control. The samples were treated with $100 \mu \mathrm{L}$ of the $220 \mu \mathrm{M}$ hematin solution in acetate $20 \mu \mathrm{L}$ and $30 \mu \mathrm{M}$ NP-40 detergent was added to induce hemozoin formation. This was followed by addition of $70 \mu \mathrm{L}$ of deionised water to give a final volume of $200 \mu \mathrm{M}$ in each well. The plate was incubated at $37^{\circ} \mathrm{C}$ for 6 hours with gentle shaking. After 6 hours, the 
analysis of hemozoin formation was carried out according to the pyridine-ferrichrome method by Ncokazi and Egan by adding to each well a solution of $50 \%$ pyridine (v/v), $20 \%$ acetone (v/v), $10 \%$ distilled water and 20\% $200 \mathrm{mM}$ HEPES buffer $(\mathrm{pH} 7.4) .{ }^{[30]}$ The plate was further incubated for 10 minutes with gentle shaking followed by addition of $50 \mu \mathrm{L}$ acetone to facilitate hemozoin dispersion. Absorbance was measured at $605 \mathrm{~nm}$ for each well and plotted against a logarithm of the corresponding concentration on GraphPad Prism 4.0. Sigmoidal non-linear regression analysis was performed to quantify hemozoin inhibition of each compound in terms $\mathrm{IC}_{50}$ values.

\section{Computational docking simulations}

The model of the hemozoin crystal was constructed with the supercell builder tool $(3 \times 3 \times 3$ unit cell) in BIOVIA Materials Studio 2017 (Dassault Systèmes BIOVIA Materials Studio 2017 v17.1.0.48, San Diego: Dassault Systèmes, 2017) using the resolved X-ray crystal structure of hemozoin (CCDC code: XETXUP01) as a template. ${ }^{[60]}$ The model was optimized according to the parameters reported by Egan and colleagues before it was used in the in silico docking simulations. ${ }^{[59]}$ The B-DNA structure was obtained from protein data bank (PDB code: 1DSI) and prepared in BIOVIA Discovery Studio Client 2019 (Dassault Systèmes BIOVIA Discovery Studio Client 2019 v19.0.18287, San Diego: Dassault Systèmes, 2019) for docking simulations. Ligand structures of the investigated compounds $(\mathbf{9 a}, \mathbf{9 j}, \mathbf{1 2 a}$ and $\mathbf{1 4 a})$ were prepared as $(S)$-planar enantiomers and minimized in Chem3D Pro 12.0, applying a minimum RMSD gradient of 0.010. The docking simulations were performed using AutoDock Vina software package and the results were analyzed in BIOVIA Discovery Studio Client 2019 and the binding energies were reported in $\mathrm{kcal} / \mathrm{mol}^{[31]}$ 


\section{ACNOWLEDGEMENTS}

The authors gratefully acknowledge the Rhodes University Sandisa Imbewu Grant (SDK, HCH, JDLM and ALE), the National Research Foundation of South Africa (MM, LMKD, TS,

DC, JL, JDM, HCH, ALE, SDK) for financial support and Thuthuka National Research Foundation (Grant No. 107270, SDK). The South African Research Chairs Initiative of the Department of Science and Technology and National Research Foundation of South Africa (Grant No. 98566) and National Research Foundation CPRR (Grant No. 105829) is also acknowledged for financial assistance (ALE). The antiplasmodial and HeLa cytotoxicity bioassay component of the project were funded by the South African Medical Research Council (SAMRC). The authors thank Professor Gilles Lemercier (Université de Reims ChampagneArdenne) for his advice regarding the prediction of the partition coefficients.

Keywords: Ferrocene, Aminocresols, Aminomethylphenols, Plasmodium falciparum, Triplenegative breast cancer, Hemozoin inhibition, DNA interaction. 


\section{REFERENCES}

[1] M. M. Gottesman, Annu. Rev. Med. 2002, 53, 615-627.

[2] B. C. Baguley, Mol. Biotechnol. 2010, 46, 308-316.

[3] G. Housman, S. Byler, S. Heerboth, K. Lapinska, M. Longacre, N. Snyder, S. Sarkar, Cancers 2014, 6, 1769-1792.

[4] M. Nikolaou, A. Pavlopoulou, A. G. Georgakilas, E. Kyrodimos, Clin. Exp. Metastasis 2018, 35, 309-318.

[5] P. Olliaro, Pharmacol. Ther. 2001, 89, 207-219.

[6] M. A. Saifi, T. Beg, A. H. Harrath, F. S. H. Altayalan, S. Al Quraishy, Afr. J. Pharm. Pharmacol. 2013, 7, 148-156.

[7] D. J. Krogstad, I. Y. Gluzman, D. E. Kyle, A. Oduola, S. K. Martin, W. K. Milhous, P. H. Schlesinger, Science 1987, 238, 1283-1285.

[8] M. Foley, L. Tilley, Pharmacol. Ther. 1998, 79, 55-87.

[9] E. Proschak, H. Stark, D. Merk, J. Med. Chem. 2018, 62, 420-444.

[10] M. d. Oliveira Pedrosa, D. da Cruz, R. Marques, J. d. Oliveira Viana, R. O. de Moura, H. M. Ishiki, F. Barbosa, J. Maria, M. F. Diniz, M. T. Scotti, Curr. Top. Med. Chem. 2017, 17, 1044-1079.

[11] C. Herrera Acevedo, L. Scotti, M. F. Alves, M. de FFM Diniz, M. Tullius Scotti, Lett. Org. Chem. 2019, 16, 81-92.

[12] M. Patra, G. Gasser, Nat. Rev. Chem 2017, 1, 0066.

[13] G. Jaouen, A. Vessières, S. Top, Chem. Soc. Rev. 2015, 44, 8802-8817.

[14] A. Singh, I. Lumb, V. Mehra, V. Kumar, Dalton Trans. 2019, 48, 2840-2860.

[15] A. Kondratskyi, K. Kondratska, F. V. Abeele, D. Gordienko, C. Dubois, R.-A. Toillon, C. Slomianny, S. Lemière, P. Delcourt, E. Dewailly, R. Skryma, C. Biot, N. Prevarskaya, Sci. Rep. 2017, 7, 1-15. 
[16] C. N. Morrison, K. E. Prosser, R. W. Stokes, A. L. Cordes, N. Metzler-Nolte, S. M. Cohen, Chem. Sci. 2020.

[17] A. W. Hung, A. Ramek, Y. Wang, T. Kaya, J. A. Wilson, P. A. Clemons, D. W. Young, Proc. Natl. Acad. Sci. U.S.A. 2011, 108, 6799-6804.

[18] J. Burckhalter, F. Tendick, E. M. Jones, W. Holcomb, A. Rawlins, J. Am. Chem. Soc. 1946, 68, 1894-1901.

[19] L. Schmidt, R. Crosby, Antimicrob. Agents Chemother. 1978, 14, 672-679.

[20] M. Chinnapattu, K. I. Sathiyanarayanan, P. S. Iyer, Bioorg. Med. Chem. Lett. 2015, 25, 952-955.

[21] H. D. Attram, S. Wittlin, K. Chibale, MedChemComm 2019, 10, 450-455.

[22] Medicines for Malaria Venture. Developing antimalarials to save lives. Malaria Box Research, $\quad$ https://www.mmv.org/mmv-open/malaria-box/malaria-box-research, Accessed: 19 November 2019.

[23] M. Mbaba, L. M. Dingle, D. Cash, J.-A. de la Mare, D. Laming, D. Taylor, H. C. Hoppe, A. L. Edkins, S. D. Khanye, Eur. J. Med. Chem. 2020, 187, 111924.

[24] C. Biot, G. Glorian, L. A. Maciejewski, J. S. Brocard, O. Domarle, G. Blampain, P. Millet, A. J. Georges, H. Abessolo, D. Dive, J. Med. Chem. 1997, 40, 3715-3718.

[25] T. Stringer, H. Guzgay, J. M. Combrinck, M. Hopper, D. T. Hendricks, P. J. Smith, K. M. Land, T. J. Egan, G. S. Smith, J. Organomet. Chem. 2015, 788, 1-8.

[26] A. F. Abdel-Magid, K. G. Carson, B. D. Harris, C. A. Maryanoff, R. D. Shah, J. Org. Chem. 1996, 61, 3849-3862.

[27] B. Saikia, Synlett 2011, 17, 2597-2598.

[28] F. Mu, D. J. Lee, D. E. Pryor, E. Hamel, M. Cushman, J. Med. Chem. 2002, 45, 47744785. 
[29] S. T. Saito, G. Silva, C. Pungartnik, M. Brendel, J. Photochem. Photobiol. B 2012, 111, $59-63$.

[30] K. K. Ncokazi, T. J. Egan, Anal. Biochem. 2005, 338, 306-319.

[31] O. Trott, A. J. Olson, J. Comput. Chem. 2010, 31, 455-461.

[32] P. M. O'Neill, S. A. Ward, N. G. Berry, J. P. Jeyadevan, G. A. Biagini, E. Asadollaly, B. K. Park, P. G. Bray, Curr. Top. Med. Chem. 2006, 6, 479-507.

[33] P. B. Madrid, A. P. Liou, J. L. DeRisi, R. K. Guy, J. Med. Chem. 2006, 49, 4535-4543.

[34] F. Dubar, T. J. Egan, B. Pradines, D. Kuter, K. K. Ncokazi, D. Forge, J.-F. Paul, C. Pierrot, H. Kalamou, J. Khalife, E. Buisine, C. Rogier, H. Vezin, I. Forfar, C. Slomianny, X. Trivelli, S. Kapishnikov, L. Leiserowitz, D. Dive, C. Biot, ACS Chem. Biol. 2011, 6, 275-287.

[35] S. Mundra, V. Thakur, A. M. Bello, S. Rathore, M. Asad, L. Wei, J. Yang, S. K. Chakka, R. Mahesh, P. Malhotra, Bioorg. Med. Chem. 2017, 25, 5662-5677.

[36] R. M. Beteck, L. J. Legoabe, M. Isaacs, S. D. Khanye, D. Laming, H. C. Hoppe, Medicina 2019, 55, 206.

[37] R. Buller, M. L. Peterson, O. Almarsson, L. Leiserowitz, Cryst. Growth Des. 2002, 2, $553-562$.

[38] W.-J. Lu, K. J. Wicht, L. Wang, K. Imai, Z.-W. Mei, M. Kaiser, I. E. T. El Sayed, T. J. Egan, T. Inokuchi, Eur. J. Med. Chem. 2013, 64, 498-511.

[39] T. Stringer, D. Taylor, C. de Kock, H. Guzgay, A. Au, S. H. An, B. Sanchez, R. O'Connor, N. Patel, K. M. Land, Eur. J. Med. Chem. 2013, 69, 90-98.

[40] G. Roman, Eur. J. Med. Chem. 2015, 89, 743-816.

[41] J. Dimmock, P. Kumar, Curr. Med. Chem. 1997, 4, 1-22.

[42] N. Shahabadi, S. Hadidi, Spectrochim. Acta A 2012, 96, 278-283.

[43] M. Sirajuddin, S. Ali, A. Badshah, J. Photochem. Photobiol. B 2013, 124, 1-19. 
[44] P. L. Hamilton, D. P. Arya, Nat. Prod. Rep. 2012, 29, 134-143.

[45] A. Lauria, A. Montalbano, P. Barraja, G. Dattolo, A. M. Almerico, Curr. Med. Chem. 2007, 14, 2136-2160.

[46] N. Shahabadi, S. Hadidi, A. A. Taherpour, Appl. Biochem. Biotechnol. 2014, 172, 24362454.

[47] N. Shahabadi, M. Maghsudi, Mol. BioSyst. 2014, 10, 338-347.

[48] J. Bucevičius, G. Lukinavičius, R. Gerasimaite, Chemosensors 2018, 6, 18.

[49] L. C. Sandhu, R. L. Warters, L. A. Dethlefsen, Cytometry A 1985, 6, 191-194.

[50] P. Vardevanyan, A. Antonyan, M. Parsadanyan, M. Shahinyan, L. Hambardzumyan, J. Appl. Spectrosc. 2013, 80, 595-599.

[51] S. Nafisi, A. A. Saboury, N. Keramat, J.-F. Neault, H.-A. Tajmir-Riahi, J. Mol. Struct. 2007, 827, 35-43.

[52] L. Aravind, L. M. Iyer, T. E. Wellems, L. H. Miller, Cell 2003, 115, 771-785.

[53] J. M. Woynarowski, M. Krugliak, H. Ginsburg, Mol. Biochem. Parasitol. 2007, 154, 70-81.

[54] M. Patra, G. Gasser, Nat. Rev. Chem 2017, 1, 1-12.

[55] Y. L. K. Tan, P. Pigeon, S. Top, E. Labbé, O. Buriez, E. A. Hillard, A. Vessières, C. Amatore, W. K. Leong, G. Jaouen, Dalton Trans. 2012, 41, 7537-7549.

[56] C. Lu, J. M. Heldt, M. Guille-Collignon, F. Lemaître, G. Jaouen, A. Vessières, C. Amatore, ChemMedChem 2014, 9, 1286-1293.

[57] C. Acevedo-Morantes, E. Meléndez, S. Singh, J. Ramírez-Vick, J. Cancer Sci. Ther. 2012, 4, 271-275.

[58] M. Maschke, J. Grohmann, C. Nierhaus, M. Lieb, N. Metzler-Nolte, ChemBioChem 2015, 16, 1333-1342. 
[59] F. P. L'abbate, R. Müller, R. Openshaw, J. M. Combrinck, K. A. de Villiers, R. Hunter, T. J. Egan, Eur. J. Med. Chem. 2018, 159, 243-254.

[60] D. S. Bohle, E. L. Dodd, P. W. Stephens, Chem. Biodivers. 2012, 9, 1891-1902.

[61] O. Takahashi, Y. Masuda, A. Muroya, T. Furuya, SAR QSAR Environ. Res. 2010, 21, $547-558$.

[62] M. Mbaba, A. N. Mabhula, N. Boel, A. L. Edkins, M. Isaacs, H. C. Hoppe, S. D. Khanye, J. Inorg. Biochem. 2017, 172, 88-93.

[63] W. Trager, J. B. Jensen, Science 1976, 193, 673-675.

[64] O. O. Oderinlo, M. Tukulula, M. Isaacs, H. C. Hoppe, D. Taylor, V. J. Smith, S. D. Khanye, Appl. Organomet. Chem. 2018, 32, e4385.

[65] M. T. Makler, D. J. Hinrichs, Am. J. Trop. M. Hyg. 1993, 48, 205-210.

[66] H. Wu, M. K. de Gannes, G. Luchetti, J. R. Pilsner, Biotechniques 2015, 58, 293-300. 